$\begin{array}{ll}\text { Research Square } & \begin{array}{l}\text { Preprints are preliminary reports that have not undergone peer review. } \\ \text { They should not be considered conclusive, used to inform clinical practice, } \\ \text { or referenced by the media as validated information. }\end{array}\end{array}$

\title{
Are children on track with their routine immunisation schedule in a fragile and protracted conflict state of South Sudan?
}

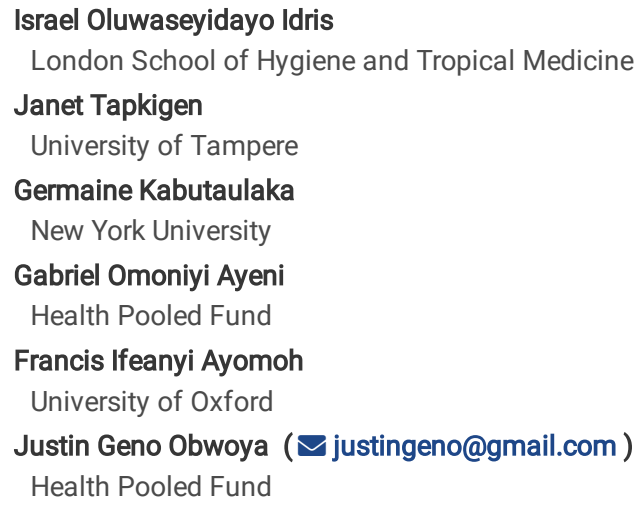

Keywords: Vaccine-preventable diseases, immunisation defaulters, Immunisation in practice, community healthcare, conflict setting, South Sudan

Posted Date: September 2nd, 2021

DOI: https://doi.org/10.21203/rs.3.rs-690583/v2

License: (c) (1) This work is licensed under a Creative Commons Attribution 4.0 International License. Read Full License 


\section{Abstract \\ Objectives}

The objective of this study was to assess if children aged 0-23 months in a conflict-affected state of South Sudan were on track with their immunisation schedule and to identify predisposing factors that affected this study population from being on track with their routine immunisation schedule.

\section{Design}

Community-based cross-sectional study using a semi-structured questionnaire. The binary outcome of interest was defined as being on or off track with routine vaccination schedule. Multivariable logistic regression was used to analyse for the association between the predisposing factors surveyed and being off track with one's routine immunisation schedule.

\section{Setting}

Rural communities in four counties (Rumbek Centre, Rumbek North, Rumbek East and Wulu) of the Western Lakes state in South Sudan during January 10 , 2020 to June 10, 2020.

\section{Participants}

We surveyed 428 children aged 0-23 months and their mothers/caregivers who lived in either of the four counties in the Western Lakes State. Participants were selected using random ballot sampling.

\section{Results}

More than three-quarters of the children surveyed (75.5\%) were off track with their vaccination schedule. Children with an immunisation card had $71 \%$ reduced odds of being off track with their immunisation ( $A O R=0.29 ; 95 \% \mathrm{Cl} 0.10-0.83$, $\mathrm{p}$-value $=0.021)$ compared to children without immunisation cards. Children who reside near health facilities and do not require transportation to facilities had $87 \%$ reduced odds of being off track with their immunisation compared to those who lived far and required transport to facilities. Giving an adequate immunisation notice before conducting immunisation outreach visits to communities was also associated with reduced odds $(A O R=0.27 ; 95 \% \mathrm{Cl} 0.09-0.78$. $p$-value $=0.016)$ of children being off track with their immunisation.

\section{Conclusion}

This study revealed that most children were off track with their vaccination schedule in South Sudan, which is not only influenced by maternal characteristics but mainly by community- and state-level immunisation service delivery mechanisms. Interventions to improve child immunisation uptake should put these contextual characteristics into high health agenda consideration.

\section{Key Points}

\section{Question}

While there is a lot of investment in immunisation in the humanitarian setting, this study is aimed at these research questions - Are children in conflict-prone regions of South Sudan on track with their immunisation schedule? And what are the predisposing factors that affected children between $0-23$ months old living in this region from being on track with their routine immunisation schedule?

\section{Finding}

This study revealed that most children were off track with their vaccination schedule in South Sudan, which is not only influenced by maternal characteristics but also by community- and state-level immunisation governance.

\section{Meaning}

This study imparts a significant deal of knowledge in improvement of immunisation uptake coverage among children living in an armed conflict context

\section{Introduction}

Since 2012, South-Sudan's full immunisation coverage has been around 47.5\%, and since then, the country has remained a conflict-prone region (1-3). Data from the WHO vaccine-preventable diseases monitoring system shows that between 2017 and 2020, there has been an alarming rate of Measles and Rubella diseases in the country $(3,4)$. The Measles outbreak in South Sudan and the increasing prevalence of vaccine-preventable diseases could be linked to the challenges with immunisation access and its cold chain logistics (5). This is as a result of the South Sudanese Civil War which lasted between December, 2013 and February 2020 with an estimate of about $50 \%$ of the cold-chain infrastructure in the country being vandalized and looted (6). The low coverage of 
vaccine-preventable diseases in South Sudan is also related to the fragile health system (1), which is bedevilled with the several challenges ranging from health workforce shortages, poor public funding of the health system, limited access to healthcare services, as well as weak vaccine surveillance and monitoring systems (7). The upsurge in some vaccine-preventable diseases clearly indicates the need for more attention to be given to immunisation in South Sudan in a bid to forestall a resultant increase in childhood mortality that could ensue. The re-emergence and increasing prevalence of vaccine-preventable diseases in South Sudan is similar to the situation in conflict-prone regions of countries such as Iraq, Syria and Yemen (8).

Arguably, children in conflict-prone regions rightfully deserve to be fully vaccinated like their peers in other parts of the world. A significant proportion of children would need to be immunized over a prolonged period for herd immunity to be attained in their region or country, and as such, the risk of a child contracting a vaccine-preventable disease is higher if more children have either not been immunized or received incomplete immunisation (9).

In accordance with global recommendations for increased vaccination coverage of at least $90 \%$ in all countries, it is imperative that vaccination coverage and completion rates in South Sudan are given high attention to ensure that the factors impeding complete vaccination coverage are identified and novel strategies employed to bridge the gap in immunisation coverage (10). This study seeks to assess if children in a conflict-prone state of South Sudan are on track with their immunisation schedule and also to identify the predisposing factors that affected children between 0-23 months old living in South Sudan from being on track with their routine immunisation schedule.

\section{Vaccination Schedule}

South Sudan has an elaborate immunisation schedule (see Appendix Table 1) where children are expected to receive a dose of of Bacille Calmette-Guérin vaccine (BCG) - given at birth or first encounter with the health system, a three-dose course of the pentavalent vaccine - given at 6,10 and 14 weeks or at least four weeks apart, four-doses of oral polio vaccine (OPV; given at birth, 6, 10 and 14 weeks), a dose of inactivated polio vaccine (IPV) - given at 14 weeks

- and a dose of measles-containing vaccine (MCV1; administered at 9 months) (11).

Table 1

a shows the distribution of the proportion of vaccine coverage by vaccine and gender

\begin{tabular}{|c|c|c|c|}
\hline \multicolumn{4}{|c|}{ Distribution of the proportion of vaccine coverage by vaccine and gender } \\
\hline \multirow[t]{3}{*}{ Variable } & \multirow{2}{*}{$\begin{array}{l}\text { Overall on track with immunization } \\
\text { Frequency }\end{array}$} & \multicolumn{2}{|c|}{ On track with immunization by Gender } \\
\hline & & Male & Female \\
\hline & $N(\%)$ & $N(\%)$ & $N(\%)$ \\
\hline \multicolumn{4}{|l|}{ BCG vaccine } \\
\hline Off track & $52(12.15)$ & $26(11.71)$ & $26(12.68)$ \\
\hline On track & $376(87.85)$ & 196(88.29) & $179(87.32)$ \\
\hline \multicolumn{4}{|l|}{ 1st dose of OPV and Pentavalent vaccine } \\
\hline Off track & $80(19.37)$ & $40(18.02)$ & $41(20.00)$ \\
\hline On track & $333(80.63)$ & $182(81.98)$ & $164(80.00)$ \\
\hline \multicolumn{4}{|c|}{ 2nd dose of OPV and Pentavalent vaccine } \\
\hline Off track & $135(35.62)$ & $74(37.56)$ & $61(33.70)$ \\
\hline On track & $244(64.38)$ & $123(62.44)$ & $120(66.30)$ \\
\hline \multicolumn{4}{|c|}{ 3rd dose of OPV and Pentavalent vaccine } \\
\hline Off track & $215(60.56)$ & $114(61.29)$ & $100(59.52)$ \\
\hline On track & $140(39.44)$ & $72(38.71)$ & $68(40.48)$ \\
\hline \multicolumn{4}{|l|}{ IPV } \\
\hline Off track & $126(35.59)$ & $68(36.56)$ & $58(34.73)$ \\
\hline On Track & $228(64.41)$ & $118(63.44)$ & $109(65.27)$ \\
\hline \multicolumn{4}{|l|}{ Measles vaccine (9-23 months) } \\
\hline Off track & $180(70.87)$ & $96(71.64)$ & $84(70.00)$ \\
\hline On track & $74(29.13)$ & $38(28.36)$ & $36(30.00)$ \\
\hline \multicolumn{4}{|c|}{ Child on/off track with immunization status } \\
\hline Children on track with immunization & $104(24.53)$ & $48(21.72)$ & $56(27.72)$ \\
\hline Children off track with immunization & 320 ( 75.47) & $173(78.28)$ & $146(72.28)$ \\
\hline
\end{tabular}


Table 1

b- Descriptive and univariate analysis for predisposing factors that affected children between 0-23 months old living in South Sudan from being on track with their routine immunisation schedule

\begin{tabular}{|c|c|c|c|c|c|}
\hline \multirow[t]{2}{*}{ Variable } & \multirow[t]{2}{*}{ Category } & \multirow{2}{*}{$\begin{array}{l}\text { On track } \\
\mathrm{N}(\%)\end{array}$} & \multirow{2}{*}{$\begin{array}{l}\text { Off track } \\
N(\%)\end{array}$} & \multicolumn{2}{|c|}{ Crude Odds Ratio } \\
\hline & & & & $\begin{array}{l}\text { OR and }(95 \% \\
\mathrm{Cl})\end{array}$ & $\begin{array}{l}\mathrm{P} \text { - } \\
\text { value }\end{array}$ \\
\hline \multicolumn{6}{|l|}{ Geographical Characteristics } \\
\hline \multirow[t]{3}{*}{ County $(\mathrm{N}=427)$} & Rumbek centre & $20(19.23$ & $\begin{array}{l}155 \\
88.57)\end{array}$ & 1 & \\
\hline & $\begin{array}{l}\text { Rumbek north and } \\
\text { Rumbek east }\end{array}$ & $3(9.23)$ & $\begin{array}{l}78 \\
(96.30)\end{array}$ & $\begin{array}{l}3.35(0.96 \\
11.63)\end{array}$ & 0.056 \\
\hline & Wulu & $\begin{array}{l}81 \\
(48.50)\end{array}$ & $\begin{array}{l}86 \\
(51.50)\end{array}$ & $\begin{array}{l}0.13(0.07 \\
0.23)\end{array}$ & $\begin{array}{l}<.001 \\
0.001\end{array}$ \\
\hline \multicolumn{6}{|l|}{ Matemal Characteristics/Role } \\
\hline \multirow[t]{3}{*}{ Parity $(\mathrm{N}=418)$} & 1 child & $\begin{array}{l}11( \\
19.30)\end{array}$ & $46(80.70$ & 1 & \\
\hline & $2-5$ children & $\begin{array}{l}59 \\
(22.52)\end{array}$ & $\begin{array}{l}203 \\
(77.48)\end{array}$ & $\begin{array}{l}0.82(0.40 \\
1.68)\end{array}$ & 0.595 \\
\hline & 6 and above & $\begin{array}{l}34 \\
(35.79)\end{array}$ & $\begin{array}{l}61 \\
(64.21)\end{array}$ & $\begin{array}{l}0.42(0.19 \\
0.93)\end{array}$ & 0.034 \\
\hline \multirow[t]{2}{*}{ Education of Mothers $(\mathrm{N}=422)$} & None & $\begin{array}{l}77 \\
(23.33)\end{array}$ & $\begin{array}{l}253 \\
(76.67)\end{array}$ & 1 & \multirow[t]{2}{*}{0.444} \\
\hline & Having some education & $\begin{array}{l}24 \\
(27.27)\end{array}$ & $\begin{array}{l}64 \\
(72.73)\end{array}$ & $\begin{array}{l}0.81 \\
(0.47,1.38)\end{array}$ & \\
\hline \multirow[t]{2}{*}{ Are you Parent/guardian of the child $(\mathrm{N}=409)$} & Parent & $\begin{array}{l}94 \\
(30.13)\end{array}$ & $\begin{array}{l}218 \\
(69.87)\end{array}$ & 1 & \multirow[t]{2}{*}{$\dot{0} 001$} \\
\hline & Guardian & $6(6.38)$ & $\begin{array}{l}88 \\
(93.62)\end{array}$ & $\begin{array}{l}\text { 6.32(2.67, } \\
14.96)\end{array}$ & \\
\hline \multirow[t]{3}{*}{ Matemal age $(\mathrm{N}=385)$} & $<24$ years & $\begin{array}{l}39 \\
(33.33)\end{array}$ & $\begin{array}{l}78 \\
(66.67)\end{array}$ & 1 & \\
\hline & $25-34$ years & $\begin{array}{l}37 \\
(20.11)\end{array}$ & $\begin{array}{l}147 \\
(79.89)\end{array}$ & $\begin{array}{l}1.98(1.17 \\
3.36)\end{array}$ & 0.011 \\
\hline & $>35$ years & $\begin{array}{l}17 \\
(21.25)\end{array}$ & $\begin{array}{l}63 \\
(78.75)\end{array}$ & $\begin{array}{l}1.85(0.95 \\
3.58)\end{array}$ & 0.067 \\
\hline \multirow[t]{2}{*}{ Availability of child immunisation card $(\mathrm{N}=411)$} & Yes & $\begin{array}{l}78 \\
(34.67)\end{array}$ & $\begin{array}{l}147 \\
(65.33)\end{array}$ & 1 & \multirow[t]{2}{*}{ ¿́.001 } \\
\hline & No & $\begin{array}{l}24 \\
(13.19)\end{array}$ & $\begin{array}{l}158 \\
(86.81)\end{array}$ & $\begin{array}{l}3.49(2.09 \\
5.81)\end{array}$ & \\
\hline \multicolumn{6}{|l|}{ Child Characteristics } \\
\hline \multirow[t]{2}{*}{$\operatorname{Sex}(N=427)$} & Male & $\begin{array}{l}48 \\
(21.72)\end{array}$ & $\begin{array}{l}173 \\
(78.28)\end{array}$ & 1 & \multirow[t]{2}{*}{0.153} \\
\hline & Female & $\begin{array}{l}56 \\
(27.72)\end{array}$ & $\begin{array}{l}146 \\
(72.28)\end{array}$ & $\begin{array}{l}0.72(0.46 \\
1.12)\end{array}$ & \\
\hline \multirow[t]{2}{*}{ Child age $(\mathrm{N}=428)$} & $0-11$ Months & $\begin{array}{l}71 \\
(26.10)\end{array}$ & $\begin{array}{l}201 \\
(73.90)\end{array}$ & 1 & \multirow[t]{2}{*}{0.314} \\
\hline & 12-23 Months & $33(21.71)$ & $\begin{array}{l}119 \\
(78.29)\end{array}$ & $\begin{array}{l}1.27(0.79 \\
2.04)\end{array}$ & \\
\hline \multicolumn{6}{|l|}{ Communal/Health System Role } \\
\hline \multirow[t]{2}{*}{ Functional health facility in the area $(\mathrm{N}=420)$} & Yes & $\begin{array}{l}99 \\
(78.29)\end{array}$ & $\begin{array}{l}285 \\
(74.22)\end{array}$ & 1 & \multirow[t]{2}{*}{0.80} \\
\hline & No & $3(10.34)$ & $\begin{array}{l}26 \\
(89.66)\end{array}$ & $\begin{array}{l}1.86(0.40 \\
8.54)\end{array}$ & \\
\hline \multirow[t]{2}{*}{ Functional facility type in the area $(\mathrm{N}=413)$} & PHCU & $\begin{array}{l}86 \\
(34.26)\end{array}$ & $\begin{array}{l}165 \\
(65.74)\end{array}$ & 1 & \multirow[t]{2}{*}{$\begin{array}{l}<.001 \\
0.00\end{array}$} \\
\hline & PHCC & $\begin{array}{l}16 \\
(10.13)\end{array}$ & $\begin{array}{l}142 \\
(89.87)\end{array}$ & $\begin{array}{l}4.63(2.59 \\
8.25)\end{array}$ & \\
\hline Distance to facility $N=(406)$ & $<=5 \mathrm{~km}$ & $\begin{array}{l}39 \\
(25.49)\end{array}$ & $\begin{array}{l}114 \\
(74.51)\end{array}$ & 1 & 0.082 \\
\hline
\end{tabular}




\begin{tabular}{|c|c|c|c|c|c|}
\hline \multirow[t]{2}{*}{ Variable } & \multirow[t]{2}{*}{ Category } & \multirow{2}{*}{$\begin{array}{l}\text { On track } \\
\mathrm{N}(\%)\end{array}$} & \multirow{2}{*}{$\begin{array}{l}\text { Off track } \\
\mathrm{N}(\%)\end{array}$} & \multicolumn{2}{|c|}{ Crude Odds Ratio } \\
\hline & & & & $\begin{array}{l}\mathrm{OR} \text { and }(95 \% \\
\mathrm{Cl})\end{array}$ & $\begin{array}{l}P- \\
\text { value }\end{array}$ \\
\hline & $6-10 \mathrm{Km}$ & $\begin{array}{l}22 \\
(18.80)\end{array}$ & $95(81.20$ & $\begin{array}{l}1.47(0.81 \\
2.66)\end{array}$ & \\
\hline & $>=11 \mathrm{Km}$ & $\begin{array}{l}41 \\
(31.06)\end{array}$ & $91(68.94)$ & $\begin{array}{l}0.75(0.45 \\
1.27)\end{array}$ & \\
\hline \multirow[t]{2}{*}{ Facility provides immunization $(\mathrm{N}=417)$} & Yes & $\begin{array}{l}99 \\
(25.78)\end{array}$ & $\begin{array}{l}285 \\
(74.22)\end{array}$ & 1 & \multirow[t]{2}{*}{0.076} \\
\hline & No & $3(10.34)$ & $\begin{array}{l}26 \\
(89.66)\end{array}$ & $\begin{array}{l}3.01(0.89 \\
10.16\end{array}$ & \\
\hline \multirow[t]{2}{*}{$\begin{array}{l}\text { Health facility conduct routine immunization outreach services }(N= \\
\text { 417) }\end{array}$} & Yes & $\begin{array}{l}84 \\
(30.11)\end{array}$ & $\begin{array}{l}195 \\
(69.89)\end{array}$ & 1 & \multirow[t]{2}{*}{0.001} \\
\hline & No & $\begin{array}{l}19 \\
(14.18)\end{array}$ & $\begin{array}{l}115 \\
(85.82)\end{array}$ & $\begin{array}{l}2.61(1.50 \\
4.51)\end{array}$ & \\
\hline \multirow[t]{2}{*}{$\begin{array}{l}\text { Frequent provision of (EPI) immunization at health facility on daily } \\
\text { bases }(\mathrm{N}=420)\end{array}$} & Yes & $\begin{array}{l}73 \\
(28.85)\end{array}$ & $\begin{array}{l}180 \\
(71.15)\end{array}$ & 1 & \multirow[t]{2}{*}{0.017} \\
\hline & No & $\begin{array}{l}30 \\
(18.40)\end{array}$ & $\begin{array}{l}133 \\
(81.60)\end{array}$ & $\begin{array}{l}1.80(1.11 \\
2.90)\end{array}$ & \\
\hline \multirow[t]{2}{*}{ Health facility Conduct mobile immunization $(\mathrm{N}=418)$} & Yes & $\begin{array}{l}56 \\
(27.72)\end{array}$ & $\begin{array}{l}146 \\
(72.28)\end{array}$ & 1 & \multirow[t]{2}{*}{0.192} \\
\hline & No & $\begin{array}{l}47 \\
(22.17)\end{array}$ & $\begin{array}{l}165 \\
(77.83)\end{array}$ & $\begin{array}{l}1.34(0.861 \\
2.10)\end{array}$ & \\
\hline \multirow[t]{2}{*}{ Is immunization good for child's health $(\mathrm{N}=416)$} & Yes & $\begin{array}{l}100 \\
(25.25)\end{array}$ & $\begin{array}{l}296 \\
(74.75)\end{array}$ & 1 & \multirow[t]{2}{*}{0.26} \\
\hline & No & $2(12.50)$ & )$^{14(87.50}$ & $\begin{array}{l}2.36(0.52 \\
10.58)\end{array}$ & \\
\hline \multirow[t]{2}{*}{ Immunization benefits $(\mathrm{N}=324)$} & $\begin{array}{l}\text { Protection against } \\
\text { diseases }\end{array}$ & $\begin{array}{l}97 \\
(33.80)\end{array}$ & $\begin{array}{l}190 \\
(66.20)\end{array}$ & 1 & \multirow[t]{2}{*}{0.012} \\
\hline & Child growth & $4(11.43)$ & $\begin{array}{l}31 \\
(88.57)\end{array}$ & $\begin{array}{l}3.96(1.35 \\
11.53)\end{array}$ & \\
\hline \multirow[t]{2}{*}{ Vaccinator conduct outreach immunization $(\mathrm{N}=409)$} & Yes & $\begin{array}{l}67 \\
(32.37)\end{array}$ & $\begin{array}{l}140 \\
(67.63)\end{array}$ & 1 & \multirow[t]{2}{*}{$\hat{0} .001$} \\
\hline & No & $\begin{array}{l}34 \\
(17.09)\end{array}$ & $\begin{array}{l}165 \\
(82.91)\end{array}$ & $\begin{array}{l}2.32(1.45, \\
3.71)\end{array}$ & \\
\hline \multirow[t]{2}{*}{ Vaccinator visit during family livelihood business $(\mathrm{N}=408)$} & Yes & $\begin{array}{l}17 \\
(14.05)\end{array}$ & $\begin{array}{l}104 \\
(85.95)\end{array}$ & 1 & \multirow[t]{2}{*}{0.001} \\
\hline & No & $\begin{array}{l}84 \\
(29.58)\end{array}$ & $\begin{array}{l}200 \\
(70.42)\end{array}$ & $\begin{array}{l}0.39(0.21 \\
0.68)\end{array}$ & \\
\hline \multirow[t]{2}{*}{$\begin{array}{l}\text { Health facility too far and no transportation to going for immunization } \\
(\mathrm{N}=410)\end{array}$} & Yes & $13(9.15)$ & $\begin{array}{l}129 \\
(90.85)\end{array}$ & 1 & \multirow[t]{2}{*}{$\dot{0} 001$} \\
\hline & No & $\begin{array}{l}89 \\
(33.58)\end{array}$ & $\begin{array}{l}176 \\
(66.42)\end{array}$ & $\begin{array}{l}0.20(9.10 \\
0.37)\end{array}$ & \\
\hline \multirow[t]{2}{*}{ Vaccinator ask for money when visit the facility for services $(N=406)$} & Yes & $3(33.33)$ & $6(66.67)$ & 1 & \multirow[t]{2}{*}{0.552} \\
\hline & No & $\begin{array}{l}97 \\
(24.62)\end{array}$ & $\begin{array}{l}297 \\
(75.38)\end{array}$ & $\begin{array}{l}1.53(0.37 \\
6.23)\end{array}$ & \\
\hline \multirow[t]{2}{*}{ Vaccinator not happy for coming regularly to the community $(N=407)$} & Yes & $3(5.08)$ & $\begin{array}{l}56 \\
(94.92)\end{array}$ & 1 & \multirow[t]{2}{*}{0.001} \\
\hline & No & $\begin{array}{l}99 \\
(28.70)\end{array}$ & $\begin{array}{l}246 \\
(71.30)\end{array}$ & $\begin{array}{l}0.13(0.04 \\
0.43)\end{array}$ & \\
\hline \multirow[t]{2}{*}{$\begin{array}{l}\text { Not completed all the immunization for my child, not informed to come } \\
\text { back }(\mathrm{N}=405)\end{array}$} & Yes & $\begin{array}{l}12 \\
(13.04)\end{array}$ & $\begin{array}{l}80 \\
(86.96)\end{array}$ & 1 & \multirow[t]{2}{*}{0.003} \\
\hline & No & $\begin{array}{l}89 \\
(28.71)\end{array}$ & $\begin{array}{l}221 \\
(71.29)\end{array}$ & $\begin{array}{l}0.37(0.19 \\
0.71)\end{array}$ & \\
\hline \multirow[t]{2}{*}{$\begin{array}{l}\text { Inadequate notice about immunization outreach visit to community }(\mathrm{N} \\
=408)\end{array}$} & Yes & $13(9.85)$ & $\begin{array}{l}119 \\
(90.15)\end{array}$ & 1 & \multirow[t]{2}{*}{$<.001$} \\
\hline & No & $\begin{array}{l}88 \\
(32.23)\end{array}$ & $\begin{array}{l}185 \\
(67.77)\end{array}$ & $\begin{array}{l}0.23(0.12 \\
0.42)\end{array}$ & \\
\hline
\end{tabular}




\begin{tabular}{|c|c|c|c|c|c|}
\hline \multirow[t]{2}{*}{ Variable } & \multirow[t]{2}{*}{ Category } & \multirow{2}{*}{$\begin{array}{l}\text { On track } \\
\mathrm{N}(\%)\end{array}$} & \multirow{2}{*}{$\begin{array}{l}\text { Off track } \\
\mathrm{N}(\%)\end{array}$} & \multicolumn{2}{|c|}{ Crude Odds Ratio } \\
\hline & & & & $\begin{array}{l}\text { OR and (95\% } \\
\text { Cl) }\end{array}$ & $\begin{array}{l}P- \\
\text { value }\end{array}$ \\
\hline \multirow[t]{2}{*}{ Girl child don't receive immunization if yes why $(N=408)$} & Yes & $3(30.00)$ & $7(70.00)$ & 1 & \multirow[t]{2}{*}{0.709} \\
\hline & No & $\begin{array}{l}98 \\
(24.81)\end{array}$ & $\begin{array}{l}297 \\
(75.19)\end{array}$ & $\begin{array}{l}1.29(0.32 \\
5.11)\end{array}$ & \\
\hline \multirow[t]{2}{*}{ Male child don't receive immunization if yes why $(N=409)$} & Yes & $3(33.33)$ & $6(66.67)$ & 1 & \multirow[t]{2}{*}{0.556} \\
\hline & No & $\begin{array}{l}98 \\
(24.69)\end{array}$ & $\begin{array}{l}299 \\
(75.31)\end{array}$ & $\begin{array}{l}1.52(0.374 \\
6.21)\end{array}$ & \\
\hline \multirow[t]{2}{*}{ Relocation history in the past 23 months $(\mathrm{N}=400)$} & Yes & $\begin{array}{l}19 \\
(29.69)\end{array}$ & $\begin{array}{l}45 \\
(70.31)\end{array}$ & 1 & \multirow[t]{2}{*}{0.395} \\
\hline & No & $\begin{array}{l}82 \\
(24.62)\end{array}$ & $\begin{array}{l}251 \\
(75.38)\end{array}$ & $\begin{array}{l}1.29(0.71 \\
2.33)\end{array}$ & \\
\hline \multirow[t]{3}{*}{ Times BHW visit household $(\mathrm{N}=345)$} & No visitation & $\begin{array}{l}10 \\
(13.70)\end{array}$ & $\begin{array}{l}63 \\
(86.30)\end{array}$ & 1 & \multirow[t]{3}{*}{$\begin{array}{l}<.001 \\
0.00\end{array}$} \\
\hline & $1-3$ times & $\begin{array}{l}24 \\
(13.87)\end{array}$ & $\begin{array}{l}149 \\
(86.13)\end{array}$ & $\begin{array}{l}0.98(0.44 \\
2.18)\end{array}$ & \\
\hline & $4-14$ times & $\begin{array}{l}47 \\
(48.96)\end{array}$ & $\begin{array}{l}49 \\
(51.04)\end{array}$ & $\begin{array}{l}0.16(0.07 \\
0.36)\end{array}$ & \\
\hline \multirow[t]{2}{*}{ Churches discussed immunization importance $(\mathrm{N}=373)$} & Yes & $\begin{array}{l}71 \\
(44.65)\end{array}$ & $\begin{array}{l}88 \\
(55.35)\end{array}$ & 1 & \multirow[t]{2}{*}{$\begin{array}{l}<.001 \\
0.001\end{array}$} \\
\hline & No & $21(9.81)$ & $\begin{array}{l}193 \\
(90.19)\end{array}$ & $\begin{array}{l}7.42(4.28 \\
12.82)\end{array}$ & \\
\hline \multirow[t]{2}{*}{ Community leaders discussed immunization importance $(N=374)$} & Yes & $\begin{array}{l}70 \\
(46.05)\end{array}$ & $\begin{array}{l}82 \\
(53.950\end{array}$ & 1 & \multirow[t]{2}{*}{$\begin{array}{l}<.001 \\
0.00\end{array}$} \\
\hline & No & $22(9.91)$ & $\begin{array}{l}200 \\
(90.09)\end{array}$ & $\begin{array}{l}7.76(4.50 \\
13.36)\end{array}$ & \\
\hline
\end{tabular}


Table 1

b- Descriptive and univariate analysis for predisposing factors that affected children between 0-23 months old living in South Sudan from being on track with their routine immunisation schedule

\begin{tabular}{|c|c|c|c|c|c|}
\hline \multirow[t]{2}{*}{ Variable } & \multirow[t]{2}{*}{ Category } & \multirow{2}{*}{$\begin{array}{l}\text { On track } \\
\mathrm{N}(\%)\end{array}$} & \multirow{2}{*}{$\begin{array}{l}\text { Off track } \\
N(\%)\end{array}$} & \multicolumn{2}{|c|}{ Crude Odds Ratio } \\
\hline & & & & $\begin{array}{l}\text { OR and }(95 \% \\
\mathrm{Cl})\end{array}$ & $\begin{array}{l}\mathrm{P} \text { - } \\
\text { value }\end{array}$ \\
\hline \multicolumn{6}{|l|}{ Geographical Characteristics } \\
\hline \multirow[t]{3}{*}{ County $(\mathrm{N}=427)$} & Rumbek centre & $20(19.23$ & $\begin{array}{l}155 \\
88.57)\end{array}$ & 1 & \\
\hline & $\begin{array}{l}\text { Rumbek north and } \\
\text { Rumbek east }\end{array}$ & $3(9.23)$ & $\begin{array}{l}78 \\
(96.30)\end{array}$ & $\begin{array}{l}3.35(0.96 \\
11.63)\end{array}$ & 0.056 \\
\hline & Wulu & $\begin{array}{l}81 \\
(48.50)\end{array}$ & $\begin{array}{l}86 \\
(51.50)\end{array}$ & $\begin{array}{l}0.13(0.07 \\
0.23)\end{array}$ & $\begin{array}{l}<.001 \\
0.001\end{array}$ \\
\hline \multicolumn{6}{|l|}{ Matemal Characteristics/Role } \\
\hline \multirow[t]{3}{*}{ Parity $(\mathrm{N}=418)$} & 1 child & $\begin{array}{l}11( \\
19.30)\end{array}$ & $46(80.70$ & 1 & \\
\hline & $2-5$ children & $\begin{array}{l}59 \\
(22.52)\end{array}$ & $\begin{array}{l}203 \\
(77.48)\end{array}$ & $\begin{array}{l}0.82(0.40 \\
1.68)\end{array}$ & 0.595 \\
\hline & 6 and above & $\begin{array}{l}34 \\
(35.79)\end{array}$ & $\begin{array}{l}61 \\
(64.21)\end{array}$ & $\begin{array}{l}0.42(0.19 \\
0.93)\end{array}$ & 0.034 \\
\hline \multirow[t]{2}{*}{ Education of Mothers $(\mathrm{N}=422)$} & None & $\begin{array}{l}77 \\
(23.33)\end{array}$ & $\begin{array}{l}253 \\
(76.67)\end{array}$ & 1 & \multirow[t]{2}{*}{0.444} \\
\hline & Having some education & $\begin{array}{l}24 \\
(27.27)\end{array}$ & $\begin{array}{l}64 \\
(72.73)\end{array}$ & $\begin{array}{l}0.81 \\
(0.47,1.38)\end{array}$ & \\
\hline \multirow[t]{2}{*}{ Are you Parent/guardian of the child $(\mathrm{N}=409)$} & Parent & $\begin{array}{l}94 \\
(30.13)\end{array}$ & $\begin{array}{l}218 \\
(69.87)\end{array}$ & 1 & \multirow[t]{2}{*}{$\dot{0} 001$} \\
\hline & Guardian & $6(6.38)$ & $\begin{array}{l}88 \\
(93.62)\end{array}$ & $\begin{array}{l}\text { 6.32(2.67, } \\
14.96)\end{array}$ & \\
\hline \multirow[t]{3}{*}{ Matemal age $(\mathrm{N}=385)$} & $<24$ years & $\begin{array}{l}39 \\
(33.33)\end{array}$ & $\begin{array}{l}78 \\
(66.67)\end{array}$ & 1 & \\
\hline & $25-34$ years & $\begin{array}{l}37 \\
(20.11)\end{array}$ & $\begin{array}{l}147 \\
(79.89)\end{array}$ & $\begin{array}{l}1.98(1.17 \\
3.36)\end{array}$ & 0.011 \\
\hline & $>35$ years & $\begin{array}{l}17 \\
(21.25)\end{array}$ & $\begin{array}{l}63 \\
(78.75)\end{array}$ & $\begin{array}{l}1.85(0.95 \\
3.58)\end{array}$ & 0.067 \\
\hline \multirow[t]{2}{*}{ Availability of child immunisation card $(\mathrm{N}=411)$} & Yes & $\begin{array}{l}78 \\
(34.67)\end{array}$ & $\begin{array}{l}147 \\
(65.33)\end{array}$ & 1 & \multirow[t]{2}{*}{ ¿́.001 } \\
\hline & No & $\begin{array}{l}24 \\
(13.19)\end{array}$ & $\begin{array}{l}158 \\
(86.81)\end{array}$ & $\begin{array}{l}3.49(2.09 \\
5.81)\end{array}$ & \\
\hline \multicolumn{6}{|l|}{ Child Characteristics } \\
\hline \multirow[t]{2}{*}{$\operatorname{Sex}(N=427)$} & Male & $\begin{array}{l}48 \\
(21.72)\end{array}$ & $\begin{array}{l}173 \\
(78.28)\end{array}$ & 1 & \multirow[t]{2}{*}{0.153} \\
\hline & Female & $\begin{array}{l}56 \\
(27.72)\end{array}$ & $\begin{array}{l}146 \\
(72.28)\end{array}$ & $\begin{array}{l}0.72(0.46 \\
1.12)\end{array}$ & \\
\hline \multirow[t]{2}{*}{ Child age $(\mathrm{N}=428)$} & $0-11$ Months & $\begin{array}{l}71 \\
(26.10)\end{array}$ & $\begin{array}{l}201 \\
(73.90)\end{array}$ & 1 & \multirow[t]{2}{*}{0.314} \\
\hline & 12-23 Months & $33(21.71)$ & $\begin{array}{l}119 \\
(78.29)\end{array}$ & $\begin{array}{l}1.27(0.79 \\
2.04)\end{array}$ & \\
\hline \multicolumn{6}{|l|}{ Communal/Health System Role } \\
\hline \multirow[t]{2}{*}{ Functional health facility in the area $(\mathrm{N}=420)$} & Yes & $\begin{array}{l}99 \\
(78.29)\end{array}$ & $\begin{array}{l}285 \\
(74.22)\end{array}$ & 1 & \multirow[t]{2}{*}{0.80} \\
\hline & No & $3(10.34)$ & $\begin{array}{l}26 \\
(89.66)\end{array}$ & $\begin{array}{l}1.86(0.40 \\
8.54)\end{array}$ & \\
\hline \multirow[t]{2}{*}{ Functional facility type in the area $(\mathrm{N}=413)$} & PHCU & $\begin{array}{l}86 \\
(34.26)\end{array}$ & $\begin{array}{l}165 \\
(65.74)\end{array}$ & 1 & \multirow[t]{2}{*}{$\begin{array}{l}<.001 \\
0.00\end{array}$} \\
\hline & PHCC & $\begin{array}{l}16 \\
(10.13)\end{array}$ & $\begin{array}{l}142 \\
(89.87)\end{array}$ & $\begin{array}{l}4.63(2.59 \\
8.25)\end{array}$ & \\
\hline Distance to facility $N=(406)$ & $<=5 \mathrm{~km}$ & $\begin{array}{l}39 \\
(25.49)\end{array}$ & $\begin{array}{l}114 \\
(74.51)\end{array}$ & 1 & 0.082 \\
\hline
\end{tabular}




\begin{tabular}{|c|c|c|c|c|c|}
\hline \multirow[t]{2}{*}{ Variable } & \multirow[t]{2}{*}{ Category } & \multirow{2}{*}{$\begin{array}{l}\text { On track } \\
\mathrm{N}(\%)\end{array}$} & \multirow{2}{*}{$\begin{array}{l}\text { Off track } \\
\mathrm{N}(\%)\end{array}$} & \multicolumn{2}{|c|}{ Crude Odds Ratio } \\
\hline & & & & $\begin{array}{l}\mathrm{OR} \text { and }(95 \% \\
\mathrm{Cl})\end{array}$ & $\begin{array}{l}P- \\
\text { value }\end{array}$ \\
\hline & $6-10 \mathrm{Km}$ & $\begin{array}{l}22 \\
(18.80)\end{array}$ & $95(81.20$ & $\begin{array}{l}1.47(0.81 \\
2.66)\end{array}$ & \\
\hline & $>=11 \mathrm{Km}$ & $\begin{array}{l}41 \\
(31.06)\end{array}$ & $91(68.94)$ & $\begin{array}{l}0.75(0.45 \\
1.27)\end{array}$ & \\
\hline \multirow[t]{2}{*}{ Facility provides immunization $(\mathrm{N}=417)$} & Yes & $\begin{array}{l}99 \\
(25.78)\end{array}$ & $\begin{array}{l}285 \\
(74.22)\end{array}$ & 1 & \multirow[t]{2}{*}{0.076} \\
\hline & No & $3(10.34)$ & $\begin{array}{l}26 \\
(89.66)\end{array}$ & $\begin{array}{l}3.01(0.89 \\
10.16\end{array}$ & \\
\hline \multirow[t]{2}{*}{$\begin{array}{l}\text { Health facility conduct routine immunization outreach services }(N= \\
\text { 417) }\end{array}$} & Yes & $\begin{array}{l}84 \\
(30.11)\end{array}$ & $\begin{array}{l}195 \\
(69.89)\end{array}$ & 1 & \multirow[t]{2}{*}{0.001} \\
\hline & No & $\begin{array}{l}19 \\
(14.18)\end{array}$ & $\begin{array}{l}115 \\
(85.82)\end{array}$ & $\begin{array}{l}2.61(1.50 \\
4.51)\end{array}$ & \\
\hline \multirow[t]{2}{*}{$\begin{array}{l}\text { Frequent provision of (EPI) immunization at health facility on daily } \\
\text { bases }(\mathrm{N}=420)\end{array}$} & Yes & $\begin{array}{l}73 \\
(28.85)\end{array}$ & $\begin{array}{l}180 \\
(71.15)\end{array}$ & 1 & \multirow[t]{2}{*}{0.017} \\
\hline & No & $\begin{array}{l}30 \\
(18.40)\end{array}$ & $\begin{array}{l}133 \\
(81.60)\end{array}$ & $\begin{array}{l}1.80(1.11 \\
2.90)\end{array}$ & \\
\hline \multirow[t]{2}{*}{ Health facility Conduct mobile immunization $(\mathrm{N}=418)$} & Yes & $\begin{array}{l}56 \\
(27.72)\end{array}$ & $\begin{array}{l}146 \\
(72.28)\end{array}$ & 1 & \multirow[t]{2}{*}{0.192} \\
\hline & No & $\begin{array}{l}47 \\
(22.17)\end{array}$ & $\begin{array}{l}165 \\
(77.83)\end{array}$ & $\begin{array}{l}1.34(0.861 \\
2.10)\end{array}$ & \\
\hline \multirow[t]{2}{*}{ Is immunization good for child's health $(\mathrm{N}=416)$} & Yes & $\begin{array}{l}100 \\
(25.25)\end{array}$ & $\begin{array}{l}296 \\
(74.75)\end{array}$ & 1 & \multirow[t]{2}{*}{0.26} \\
\hline & No & $2(12.50)$ & )$^{14(87.50}$ & $\begin{array}{l}2.36(0.52 \\
10.58)\end{array}$ & \\
\hline \multirow[t]{2}{*}{ Immunization benefits $(\mathrm{N}=324)$} & $\begin{array}{l}\text { Protection against } \\
\text { diseases }\end{array}$ & $\begin{array}{l}97 \\
(33.80)\end{array}$ & $\begin{array}{l}190 \\
(66.20)\end{array}$ & 1 & \multirow[t]{2}{*}{0.012} \\
\hline & Child growth & $4(11.43)$ & $\begin{array}{l}31 \\
(88.57)\end{array}$ & $\begin{array}{l}3.96(1.35 \\
11.53)\end{array}$ & \\
\hline \multirow[t]{2}{*}{ Vaccinator conduct outreach immunization $(\mathrm{N}=409)$} & Yes & $\begin{array}{l}67 \\
(32.37)\end{array}$ & $\begin{array}{l}140 \\
(67.63)\end{array}$ & 1 & \multirow[t]{2}{*}{$\hat{0} .001$} \\
\hline & No & $\begin{array}{l}34 \\
(17.09)\end{array}$ & $\begin{array}{l}165 \\
(82.91)\end{array}$ & $\begin{array}{l}2.32(1.45, \\
3.71)\end{array}$ & \\
\hline \multirow[t]{2}{*}{ Vaccinator visit during family livelihood business $(\mathrm{N}=408)$} & Yes & $\begin{array}{l}17 \\
(14.05)\end{array}$ & $\begin{array}{l}104 \\
(85.95)\end{array}$ & 1 & \multirow[t]{2}{*}{0.001} \\
\hline & No & $\begin{array}{l}84 \\
(29.58)\end{array}$ & $\begin{array}{l}200 \\
(70.42)\end{array}$ & $\begin{array}{l}0.39(0.21 \\
0.68)\end{array}$ & \\
\hline \multirow[t]{2}{*}{$\begin{array}{l}\text { Health facility too far and no transportation to going for immunization } \\
(\mathrm{N}=410)\end{array}$} & Yes & $13(9.15)$ & $\begin{array}{l}129 \\
(90.85)\end{array}$ & 1 & \multirow[t]{2}{*}{$\dot{0} 001$} \\
\hline & No & $\begin{array}{l}89 \\
(33.58)\end{array}$ & $\begin{array}{l}176 \\
(66.42)\end{array}$ & $\begin{array}{l}0.20(9.10 \\
0.37)\end{array}$ & \\
\hline \multirow[t]{2}{*}{ Vaccinator ask for money when visit the facility for services $(N=406)$} & Yes & $3(33.33)$ & $6(66.67)$ & 1 & \multirow[t]{2}{*}{0.552} \\
\hline & No & $\begin{array}{l}97 \\
(24.62)\end{array}$ & $\begin{array}{l}297 \\
(75.38)\end{array}$ & $\begin{array}{l}1.53(0.37 \\
6.23)\end{array}$ & \\
\hline \multirow[t]{2}{*}{ Vaccinator not happy for coming regularly to the community $(N=407)$} & Yes & $3(5.08)$ & $\begin{array}{l}56 \\
(94.92)\end{array}$ & 1 & \multirow[t]{2}{*}{0.001} \\
\hline & No & $\begin{array}{l}99 \\
(28.70)\end{array}$ & $\begin{array}{l}246 \\
(71.30)\end{array}$ & $\begin{array}{l}0.13(0.04 \\
0.43)\end{array}$ & \\
\hline \multirow[t]{2}{*}{$\begin{array}{l}\text { Not completed all the immunization for my child, not informed to come } \\
\text { back }(\mathrm{N}=405)\end{array}$} & Yes & $\begin{array}{l}12 \\
(13.04)\end{array}$ & $\begin{array}{l}80 \\
(86.96)\end{array}$ & 1 & \multirow[t]{2}{*}{0.003} \\
\hline & No & $\begin{array}{l}89 \\
(28.71)\end{array}$ & $\begin{array}{l}221 \\
(71.29)\end{array}$ & $\begin{array}{l}0.37(0.19 \\
0.71)\end{array}$ & \\
\hline \multirow[t]{2}{*}{$\begin{array}{l}\text { Inadequate notice about immunization outreach visit to community }(\mathrm{N} \\
=408)\end{array}$} & Yes & $13(9.85)$ & $\begin{array}{l}119 \\
(90.15)\end{array}$ & 1 & \multirow[t]{2}{*}{$<.001$} \\
\hline & No & $\begin{array}{l}88 \\
(32.23)\end{array}$ & $\begin{array}{l}185 \\
(67.77)\end{array}$ & $\begin{array}{l}0.23(0.12 \\
0.42)\end{array}$ & \\
\hline
\end{tabular}




\begin{tabular}{|c|c|c|c|c|c|}
\hline \multirow[t]{2}{*}{ Variable } & \multirow[t]{2}{*}{ Category } & \multirow{2}{*}{$\begin{array}{l}\text { On track } \\
\mathrm{N}(\%)\end{array}$} & \multirow{2}{*}{$\begin{array}{l}\text { Off track } \\
\mathrm{N}(\%)\end{array}$} & \multicolumn{2}{|c|}{ Crude Odds Ratio } \\
\hline & & & & $\begin{array}{l}\mathrm{OR} \text { and }(95 \% \\
\mathrm{Cl})\end{array}$ & $\begin{array}{l}\text { P- } \\
\text { value }\end{array}$ \\
\hline \multirow[t]{2}{*}{ Girl child don't receive immunization if yes why $(N=408)$} & Yes & $3(30.00)$ & $7(70.00)$ & 1 & \multirow[t]{2}{*}{0.70} \\
\hline & No & $\begin{array}{l}98 \\
(24.81)\end{array}$ & $\begin{array}{l}297 \\
(75.19)\end{array}$ & $\begin{array}{l}1.29(0.32, \\
5.11)\end{array}$ & \\
\hline \multirow[t]{2}{*}{ Male child don't receive immunization if yes why $(\mathrm{N}=409)$} & Yes & $3(33.33)$ & $6(66.67)$ & 1 & \multirow[t]{2}{*}{0.55} \\
\hline & No & $\begin{array}{l}98 \\
(24.69)\end{array}$ & $\begin{array}{l}299 \\
(75.31)\end{array}$ & $\begin{array}{l}1.52(0.374 \\
6.21)\end{array}$ & \\
\hline \multirow[t]{2}{*}{ Relocation history in the past 23 months $(\mathrm{N}=400)$} & Yes & $\begin{array}{l}19 \\
(29.69)\end{array}$ & $\begin{array}{l}45 \\
(70.31)\end{array}$ & 1 & \multirow[t]{2}{*}{0.39} \\
\hline & No & $\begin{array}{l}82 \\
(24.62)\end{array}$ & $\begin{array}{l}251 \\
(75.38)\end{array}$ & $\begin{array}{l}\text { 1.29(0.71, } \\
2.33)\end{array}$ & \\
\hline \multirow[t]{3}{*}{ Times BHW visit household $(\mathrm{N}=345)$} & No visitation & $\begin{array}{l}10 \\
(13.70)\end{array}$ & $\begin{array}{l}63 \\
(86.30)\end{array}$ & 1 & \multirow[t]{3}{*}{$\delta_{0.00}$} \\
\hline & $1-3$ times & $\begin{array}{l}24 \\
(13.87)\end{array}$ & $\begin{array}{l}149 \\
(86.13)\end{array}$ & $\begin{array}{l}0.98(0.44 \\
2.18)\end{array}$ & \\
\hline & $4-14$ times & $\begin{array}{l}47 \\
(48.96)\end{array}$ & $\begin{array}{l}49 \\
(51.04)\end{array}$ & $\begin{array}{l}0.16(0.07 \\
0.36)\end{array}$ & \\
\hline \multirow[t]{2}{*}{ Churches discussed immunization importance $(\mathrm{N}=373)$} & Yes & $\begin{array}{l}71 \\
(44.65)\end{array}$ & $\begin{array}{l}88 \\
(55.35)\end{array}$ & 1 & \multirow[t]{2}{*}{$\begin{array}{l}< \\
0.00\end{array}$} \\
\hline & No & $21(9.81)$ & $\begin{array}{l}193 \\
(90.19)\end{array}$ & $\begin{array}{l}7.42(4.28 \\
12.82)\end{array}$ & \\
\hline \multirow[t]{2}{*}{ Community leaders discussed immunization importance $(\mathrm{N}=374)$} & Yes & $\begin{array}{l}70 \\
(46.05)\end{array}$ & $\begin{array}{l}82 \\
(53.950\end{array}$ & 1 & \multirow[t]{2}{*}{$<.001$} \\
\hline & No & $22(9.91)$ & $\begin{array}{l}200 \\
(90.09)\end{array}$ & $\begin{array}{l}7.76(4.50 \\
13.36)\end{array}$ & \\
\hline
\end{tabular}

\section{Methods}

\subsection{Study setting}

This study was conducted in the rural communities of the four counties - Rumbek Centre, Rumbek North, Rumbek East, and Wulu in the former Western Lakes State (see Fig. 2). The former Western Lakes state was a state in South Sudan that was abrogated to function as a state during the peace agreement signed on the 22nd of February 2020, with an aim to reduce the former 28 states to the current 10 states $(12,13)$. Rumbek East, Wulu, Rumbek North and Rumbek Centre counties have a population of 186,$412 ; 61,084 ; 65,297$ and 232,752 in the July 2017 projection population estimate respectively (14).

Since 2005, the former Western Lakes state region, one of the most insecure areas of South Sudan has experienced yearly series of armed conflict and displacement caused by different reasons per county. From land, agricultural and water disputes to armed robberies, these violent occurrences have sustained the insecurity in South Sudan (15). This has been worsened by re-occurrence of natural disasters e.g. heavy (destructive) flooding during the wet season (16).

\subsection{Study Design}

The study is a comparative community-based cross-sectional study to determine the predisposing factors for on track and off track immunisation among children between 0-23 months in South Sudan. The study was conducted in the communities, also called bomas of the four counties aforementioned using a semi-structured questionnaire. The binary outcome was defined as whether children aged 0-23 months were on track with their immunisation schedule or off track. Being on track was defined as when a child who was eligible for vaccination had received the recommended vaccines' doses they were due for at the time of the study survey. Off track was defined as if a child had not received a vaccine they were eligible for on or after 28 days of delay according to South Sudan's recommended schedule (17).

Information about immunisation was extracted from the child's immunisation card or as reported by the mother and verified on the immunisation register.

\subsection{Sampling and Sample size determination}

We sampled 428 children and their mothers/caregivers using random balloting sampling.

The number of children under 24 months required for this study was determined using the Leisle Kish formula (18, 19), with the assumption margin of $5 \%$ margin of error (d), 95\% confidence interval level (Z) and the immunisation coverage assumed as $56.5 \%(20)$ taken from a study done in Juba on missed immunisation. The sample was calculated as follows:

Where: 
$\mathrm{P}=$ proportion of vaccine uptake or immunisation defaulters or immunisation refusal.

$q=1-p$

$\mathrm{d}=$ precision $(5 \%)$

Adjusting for a $13.5 \%$ rate of non-responses and invalid Response

$\mathrm{n}_{\mathrm{s}}=\mathrm{n} /$ expected response rate

$\mathrm{n}_{\mathrm{s}}=377 / 0.865$

$\mathrm{n}_{\mathrm{s}}=435$

\subsection{Data collection procedure}

Data collection was carried out by three integrated community case management (ICCM) workers per boma who volunteered and collected data between January 10, 2020 and June 10, 2020. The volunteers were given a 2-day orientation on administering the questionnaire. The questionnaire was adopted from the demographic and health survey of Ethiopia (21) and the WHO's questionnaire $(22,23)$, with slight modifications based on the study site context. Inclusion criteria of participants included mothers and caregivers above 16 years-old with children aged 0-23 months. Immunisation history of a child was primarily obtained from their respective immunisation cards; wherein if lost or unavailable, immunisation history was obtained from the mothers'/caregivers' recall which was verified from the immunisation register at the health centre where the immunisation was taken, with the exception for BCG which the scar proved as evidence. Children with untraceable immunisation records were excluded to minimise recall bias.

\subsection{Statistical analysis}

Maternal age was regrouped into below 24 years, $25-34$ years and above 35 years. Age of the child was grouped into 0-11 months and $12-23$ months. Birth order of the child was categorised into 1 st child, 2 nd-5th order and 6 th + order. Maternal education was defined as none and having some education. Sex of the child was defined as female and male. Distance to the health facility was categorised into $<=5 \mathrm{Km}, 6-10 \mathrm{KM}$ and $>=11 \mathrm{Km}$.

Primary quantitative data was entered into Microsoft Excel and imported into STATA 15 for analysis. Missing data was observed and accounted for in the analysis and reported in the tables. Four approaches were used to analyse the data. First, we performed descriptive analyses to compute the frequencies and percentages of the variables. Second, crude odds ratio (COR) with $95 \%$ confidence intervals (Cl) were estimated using univariate logistic regression to quantify the relationship between the outcome with the independent variables. The univariate analysis was used to identify factors that were independently associated with the outcome. Third, factors that were statistically associated with the outcome in the univariate analysis were treated as main exposures and adjusted for potential confounders using the Mantel-Haenszel method. Crude odds ratio from the univariate analysis was compared with the Mantel-Haenszel's OR to identify potential confounders. Homogeneity testing was conducted to compare stratum specific odds ratios in order to identify effect modification. Lastly, the potential confounders were entered into a multi-level multivariable and forward selection stepwise multivariable logistic regression models to control for them. Factors treated as main exposures included in the models included parity, frequent provision of immunisation at health facility on daily basis, immunisation benefits, vaccinator conducting outreach immunisation, vaccinator visiting during family livelihood/ business hours, health facility is too far and no transportation means to visit health facility for immunisation, inadequate notice about immunisation outreach visit to community, churches discussed immunisation importance, community leaders discussed immunisation importance. Prior to fitting the multivariable models, we assessed for collinearity using the Pearson's R correlation coefficient $(r>=0.8)$, and retained predictors that were within the recommended range as suggested in the literature (24)

Variables with collinearity include religion, marital status, fear of side effects and abusive vaccinators. These variables had all or very few observations in one group, thus, no variations. Estimates with a p-value less than significance level (5\%) were considered statistically significant. Odds ratios (OR), p-values and lower and upper $95 \%$ confidence intervals of the variables that were included in the model are presented.

\subsection{Ethical consideration}

\section{Ethical approval}

for the study was obtained from the Ministry of Health in South Sudan. Permission to conduct the study was obtained from the state manager of the extended programme on immunisation and the director of primary healthcare, state ministry of health. Prior to completing the questionnaires, participants were given information about the study and written informed consent was obtained. Participants were informed of their right to voluntary participation in the study.

\section{Results}

\section{Participant characteristics}

Four hundred and twenty eight mothers and caregivers of children aged 0-23 months were included in this study. The median age of the children in the study was 10 months, with $64 \%$ (274/428) being $0-11$ months and $52.0 \%$ (222/427) being boys. Mothers made up 76.5\% of the respondents (313/409) compared to caregivers. The median age of the mothers and caregivers was 28 years (age range 15-52) with a majority of the mothers and caregivers (48.6\%) between 25-34 years. Majority of the respondents (78.7\%) had no formal education. Mothers with $2-5$ children formed the largest proportion ( $63.4 \%$ ) of participants. Over half (55.2\%) of the children reported having immunisation cards.

\section{Immunisation status}


Overall, findings from this study showed that $75.5 \%$ (320/424) of the children were off track with immunisation (Table 1a). There was no difference in the proportion of children being off track with immunisation ( $p$ value $=0.152)$ between female children $(78.3 \%)$ and male children $(72.3 \%)$. Compared to the rest of the recommended vaccination doses, BCG had the least proportion of children being off track with immunisation (12.2\%, 52/428). For vaccines with more than one dose, such as Penta and OPV, the proportion of children being off track with immunisation increased in subsequent immunisation doses than preceding doses. For instance, while only $19.4 \%$ (80/413) of children were off track with the 1 st dose of the pentavalent vaccination, more than half (60.6\%, 215/355) of the children were off track with the 3rd dose of the pentavalent vaccination.

\section{Factors associated with being off track with immunisation}

In the univariate analysis (see Table 1b), there was a strong statistical association between being off track with immunisation and being in Wulu County (crude odds ratio (cOR) 0.13, 95\% Cl: 0.07-0.23); mothers with 6 and above children (cOR 0.42, 95\% Cl: 0.19-0.93); being a guardian (cOR 6.32, 95\% Cl: 2.6714.96); maternal age 25-34 years (cOR 1.98, 95\% Cl: 1.17-3.36); immunisation card unavailable (COR 3.49, 95\% $\mathrm{Cl} 2.09-5.81$ ); functional facility being a Primary Health Care Center (cOR 4.63, 95\% Cl: 2.59-8.25); health facility does not conduct routine immunisation outreach (cOR 2.61, 95\% Cl: 1.50-4.51); no frequent provision of (EPI) immunisation at health facility (COR 1.80; 95\% Cl: 1.11-2.90); Immunisation benefits being child growth (cOR 3.96, Cl 95\% (1.35, 11.53); no vaccinator conducting outreach immunisation (COR 2.32, Cl 95\% 1.45-3.71); vaccinator comes during family livelihood business time (cOR 0.39 , $95 \% \mathrm{Cl} 0.21-0.68$ ); for health facility in close proximity with transportation (cOR $0.20,95 \% \mathrm{Cl} 0.10-0.37$ ); vaccinator are happy to regularly come to the community (cOR $0.13,95 \% \mathrm{Cl} 0.04-0.43$ ); completed all immunization for child and informed to come back (cOR 0.37, 95\% Cl 0.19, 0.71); Adequate notice about immunization outreach visit to community (cOR 0.23, 95\% Cl 0.12-0.42); boma health workers visiting household 4-14 times (cOR $0.1695 \% \mathrm{Cl} 0.07-$ 0.36 ); churches not discussing immunisation importance (COR 7.42, 95\% Cl 4.28-12.82); and community leaders not discussing immunization importance (cOR 7.76 95\% Cl 4.50-13.36). In addition, there were potential confounding effects on the above associations. For example, and as seen in Table 2, after adjusting for maternal age, children whose mothers and caregivers had adequate notice about immunization outreach were about $90 \%$ less likely to be off track with immunisation compared to those who did not receive adequate notice (cOR $0.11,95 \% \mathrm{Cl} 0.04-0.29$ ). 
Table 2

shows the adjusted estimates of the odds ratio for the main exposure

Adjusted estimates of the odds ratio for the main exposures influencing children between 0-23 months old living in South Sudan from being on track with their routine immunisation schedule using Mantel-Haenszel method

Variables

Crude Estimates

Crude OR $(95 \% \mathrm{Cl})$

$0.42(0.19,0.93)$

0.034

$0.40(0.24,0.65)$

$<0.001$

Immunization benefits adjusted for :

Maternal Age (25-34 years)

$3.96(1.35,11.53)$

0.012

\begin{tabular}{ll}
$3.82(1.25,11.60)$ & 0.011 \\
\hline $3.50(1.18,10.34)$ & 0.016 \\
\hline $3.95(1.27,12.23)$ & 0.01
\end{tabular}

Health facility too far and no transportation to going for immunization

Frequent provision of immunization at health facility on daily basis adjusted for :

County

$1.80(1.11,2.90)$

0.017

$1.20(0.70,2.03)$

0.494

Availability of children immunization card

Functional health facility in the area

Health facility conduct routine immunization outreach services

Health facility too far and no transportation to going for immunization

Vaccinator not happy for coming regularly to the community

Inadequate notice about immunization outreach visit to community

$1.62(0.97,2.69)$

0.059

$1.64(0.98,2.73)$

0.054

$1.33(0.77,2.27)$

0.303

$1.53(0.92,2.53)$

0.099

$1.54(0.94,2.53)$

0.083

$1.32(0.78,2.22)$

0.293

vaccinator conduct outreach immunization adjusted for :

Maternal Age (25-34 years)

$2.32(1.45,3.71)$

$<0.001$

$2.15(1.27,3.63)$

0.003

immunization benefits

Vaccinator visit during family livelihood business

Health facility too far and no transportation to going for immunization

Not completed all the immunization for my child, not informed to come back

$2.06(1.231,3.43)$

0.005

$2.23(1.36,3.61)$

0.001

$2.31(1.40,3.78)$

0.001

$2.26(1.39,3.65)$

0.001

Vaccinator visit during family livelihood business adjusted for :

Availability of children immunization card

$0.39(0.21,0.68)$

0.001

$0.35(0.19,0.64)$

0.001

Functional facility type in the area

Health facility conduct routine immunization outreach services

$0.35(0.19,0.64)$

$<0.001$

$0.36(0.19,0.66)$

0.001

Health facility too far and no transportation to going for immunization adjusted for :

Functional facility type in the area

$0.20(9.10,0.37)$

$<0.001$

$0.15(0.07,0.29)$

$<0.001$

Inadequate notice about immunization outreach visit to community

$0.20(0.10,0.37)$

$<0.001$

Inadequate notice about immunization outreach visit to community adjusted for :

Parity (above 6 children)

$0.23(0.12,0.42)$

$<0.001$

$0.22(0.11,0.42)$

$<0.001$

Availability of children immunization card

Maternal Age

Vaccinator conduct outreach immunization

Health facility too far and no transportation to going for immunization

Vaccinator not happy for coming regularly to the community

$0.24(0.12,0.45)$

$<0.001$

$0.11(0.04,0.29)$

$<0.001$

$0.19(0.09,0.36)$

$<0.001$

$0.22(0.11,0.42)$

$<0.001$

$0.28(0.14,0.53)$

$<0.001$

Churches discussed immunization importance adjusted for :

County

$7.42(4.28,12.82)$

$<0.001$

$2.42(1.15,5.11)$

0.016

Availability of children immunization card

Functional facility type in the area

Health facility conduct routine immunization outreach services

$6.90(3.63,13.06)$

$<0.001$

$6.60(3.46,12.54)$

$<0.001$

$6.94(3.66,13.15)$

$<0.001$ 


\begin{tabular}{|c|c|c|c|c|}
\hline \multicolumn{5}{|c|}{$\begin{array}{l}\text { Adjusted estimates of the odds ratio for the main exposures influencing children between } 0-23 \text { months old living in South Sudan from being on track with } \\
\text { their routine immunisation schedule using Mantel-Haenszel method }\end{array}$} \\
\hline Frequent provision of immunization at health facility on daily bases & & & $6.90(3.94,12.09)$ & $<0.001$ \\
\hline Vaccinator visit during family livelihood business & & & $6.48(3.56,11.76)$ & $<0.001$ \\
\hline Health facility too far and no transportation to going for immunization & & & $6.07(3.28,11.21)$ & $<0.001$ \\
\hline Not completed all the immunization for my child, not informed to come back & & & $6.59(3.58,12.11)$ & $<0.001$ \\
\hline Inadequate notice about immunization outreach visit to community & & & $6.91(3.78,12.61)$ & $<0.001$ \\
\hline Community leaders discussed immunization importance & & & $2.29(0.98,5.35)$ & 0.049 \\
\hline Are you Parent/guardian of the child & & & $6.38(3.26,12.45)$ & $<0.001$ \\
\hline \multicolumn{5}{|l|}{ Community discussed immunization importance adjusted for : } \\
\hline Availability of children immunization card & \multirow{11}{*}{\multicolumn{2}{|c|}{$7.76(4.50,13.36)$}} & $6.43(3.40,12.16)$ & $<0.001$ \\
\hline Functional facility type in the area & & & $6.81(3.50,13.25)$ & $<0.001$ \\
\hline Health facility conduct routine immunization outreach services & & & $7.61(3.90,14.85)$ & $<0.001$ \\
\hline Frequent provision of immunization at health facility on daily bases & & & $7.52(4.22,13.41)$ & $<0.001$ \\
\hline Vaccinator visit during family livelihood business & & & $6.86(3.78,12.45)$ & $<0.001$ \\
\hline Health facility too far and no transportation to going for immunization & & & $6.57(3.54,12.16)$ & $<0.001$ \\
\hline Not completed all the immunization for my child, not informed to come back & & & $6.98(3.78,12.84)$ & $<0.001$ \\
\hline Inadequate notice about immunization outreach visit to community & & & $6.83(3.68,12.63)$ & $<0.001$ \\
\hline Churches discussed immunization importance & & & $3.14(1.33,7.38)$ & 0.006 \\
\hline Are you Parent/guardian of the child & & & $6.71(3.44,13.03)$ & $<0.001$ \\
\hline Parity (above 6 children) & & & $7.00(3.87,12.65)$ & $<0.001$ \\
\hline
\end{tabular}

\section{Multivariable analysis}

The stepwise multivariable logistic regression models results (see Table 3 ) showed that the predisposing factors that mainly were associated with the study population's immunization status was not children's characteristics such as sex and age, but rather, by community- and state-level contexts. In fact, children were up to more than 2 times more likely to be off track with immunization when there was no vaccinator conducting outreach immunization compared to when there was (OR $2.27,95 \% \mathrm{Cl} 1.29-3.96)$. The probability of a child being off track for immunization was reduced by $85 \%$ for those who lived close to health facilities and had transportation compared to those who did not (OR $0.15,95 \% \mathrm{Cl} 0.07-0.28)$. Children whose mothers and caregivers had adequate notice about immunization outreach were up to $85 \%$ less likely to be off track with immunisation compared to those who did not receive adequate notice (OR $0.15,95 \% \mathrm{Cl} 0.07-0.28)$. Lastly, it was observed that the absence of community engagement discussing immunization importance in both the church (OR $2.42,95 \% \mathrm{Cl} 1.16-5.01)$ and from the greater community (OR 3.62,95\% Cl1.42-9.18) increased the odds of children being off track with immunization compared to communities that did engage. 
Table 3

Factors associated with on track status with immunization by multilevel multivariate logistics regression

\begin{tabular}{|c|c|c|c|c|}
\hline \multicolumn{5}{|c|}{$\begin{array}{l}\text { Multilevel multivariate logistics regression models to identify the predisposing factors that affected children between } 0-23 \text { months old living in South } \\
\text { Sudan from being on track with their routine immunisation schedule. }\end{array}$} \\
\hline \multirow[t]{2}{*}{ Variable } & $\begin{array}{l}\text { Crude } \\
\text { Estimate }\end{array}$ & Model 1a & Model $2 b$ & Model 3c \\
\hline & $\operatorname{cOR}(\mathrm{Cl})$ & aOR (Cl) & aOR (Cl) & aOR (Cl) \\
\hline
\end{tabular}

Individual-level factors

Matemal and Child Characteristics

Parity

1 child

$\begin{array}{llll}\begin{array}{lll}1 \\ \text { (reference) }\end{array} & \begin{array}{l}1 \text { (reference) } \\ \text { (refence) }\end{array} & \begin{array}{l}1 \\ \text { (reference) }\end{array} \\ 0.82(0.40, & \begin{array}{lll}0.55(0.23, \\ 1.28) \#\end{array} & \begin{array}{l}0.58(0.18, \\ 1.68)\end{array} & \begin{array}{l}1.01(0.45 \\ 2.23) \#\end{array} \\ 0.43(0.19, & \begin{array}{l}0.28(0.09, \\ 0.93)\end{array} & \begin{array}{l}0.32(0.08, \\ 1.12) \#\end{array} & \begin{array}{l}0.40(0.16 \\ 0.96)\end{array}\end{array}$

\section{Community Characteristics}

Immunization benefits

Protection against diseases

\begin{tabular}{llll}
$\begin{array}{l}1 \\
\text { (reference) }\end{array}$ & $\begin{array}{l}1 \\
\text { (reference) }\end{array}$ & 1 (reference) & $\begin{array}{l}1 \\
\text { (reference) }\end{array}$ \\
\hline 3.96 & $5.94(1.70$, & 23.05 & 7.45 \\
$(1.35,11.53)$ & $20.71)$ & $(2.81,188.68)$ & \\
& & & 2.06 \\
& & & $26.87)$
\end{tabular}

Churches discussed immunization importance

\begin{tabular}{|c|c|c|c|c|}
\hline Yes & $\begin{array}{l}1 \\
\text { (reference) }\end{array}$ & $\begin{array}{l}1 \\
\text { (reference) }\end{array}$ & 1 (reference) & $\begin{array}{l}1 \\
\text { (reference) }\end{array}$ \\
\hline No & $\begin{array}{l}7.42 \\
(4.28,12.82)\end{array}$ & $\begin{array}{l}5.75(2.79 \\
11.80)\end{array}$ & $\begin{array}{l}1.62 \\
(0.60,4.37) \#\end{array}$ & $\begin{array}{l}7.62 \\
(3.90 \\
14.87)\end{array}$ \\
\hline \multicolumn{5}{|c|}{ Community discussed immunization importance } \\
\hline Yes & $\begin{array}{l}1 \\
\text { (reference) }\end{array}$ & $\begin{array}{l}1 \\
\text { (reference) }\end{array}$ & 1 (reference) & $\begin{array}{l}1 \\
\text { (reference) }\end{array}$ \\
\hline No & $\begin{array}{l}7.76 \\
(4.50,13.36)\end{array}$ & $\begin{array}{l}5.62(2.6 \\
11.86)\end{array}$ & $\begin{array}{l}1.77(0.58 \\
5.34) \#\end{array}$ & $\begin{array}{l}8.01(4.02, \\
15.92)\end{array}$ \\
\hline
\end{tabular}

State (health system) related factors

Frequent provision of immunization at health facility on daily bases

Yes

$\begin{array}{lll}1 & 1 \text { (reference) } 1\end{array}$

(reference) (reference) (reference)

No

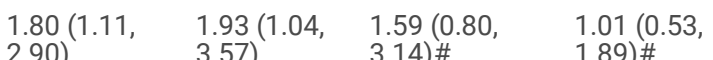

Vaccinator conduct outreach immunization

Yes

\begin{tabular}{|c|c|c|c|}
\hline $\begin{array}{l}1 \\
\text { (reference) }\end{array}$ & $\begin{array}{l}1 \\
\text { (reference) }\end{array}$ & 1 (reference) & $\begin{array}{l}1 \\
\text { (reference) }\end{array}$ \\
\hline $5,3.71$ & $\begin{array}{l}2.27(1.29 \\
3.98)\end{array}$ & $\begin{array}{l}4.12(1.91, \\
8.88)\end{array}$ & $\begin{array}{l}7.21(3.82 \\
13.5)\end{array}$ \\
\hline
\end{tabular}

Vaccinator visit during family livelihood business

\# means it is not statistically significant ( $p$ value $>0.05$ )

Model 1: Association is adjusted for Maternal Age + parity + parent/guardian + child availability card

Model 2: Association is adjusted for immunisation benefit + community discussed + church discussed + Vaccinator visit during family livelihood business + BHWs + Health facility too far and no transportation to go for immunization.

Model 3: Association is adjusted for Functional facility type in the area + Health facility conduct routine immunization outreach services + vaccinator not happy + did not inform to come back + frequent provision of immunisation at the health facilities + inadequate notice + health facility conduct routine immunisation 
Multilevel multivariate logistics regression models to identify the predisposing factors that affected children between $0-23$ months old living in South Sudan from being on track with their routine immunisation schedule.

\begin{tabular}{|c|c|c|c|c|}
\hline Yes & $\begin{array}{l}1 \\
\text { (reference) }\end{array}$ & $\begin{array}{l}1 \\
\text { (reference) }\end{array}$ & 1 (reference) & $\begin{array}{l}1 \\
\text { (reference) }\end{array}$ \\
\hline No & $\begin{array}{l}0.40 \\
(0.21,0.68)\end{array}$ & $\begin{array}{l}0.56 \\
(0.29,1.09)\end{array}$ & $\begin{array}{l}0.32(0.13 \\
0.73)\end{array}$ & $\begin{array}{l}0.43(0.23, \\
0.80)\end{array}$ \\
\hline
\end{tabular}

Health facility too far and no transportation to going for immunization

Yes

1 (reference) $\quad 1$ (reference) 1

No

\begin{tabular}{|c|c|c|}
\hline $\begin{array}{l}0.20 \\
0.10,0.37)\end{array}$ & $\begin{array}{l}0.26(0.12 \\
0.54)\end{array}$ & $\begin{array}{l}0.19(0.07, \\
0.48)\end{array}$ \\
\hline
\end{tabular}

Inadequate notice about immunization outreach visit to community

\begin{tabular}{|c|c|c|c|c|}
\hline Yes & $\begin{array}{l}1 \\
\text { (reference) }\end{array}$ & $\begin{array}{l}1 \\
\text { (reference) }\end{array}$ & 1 (reference) & $\begin{array}{l}1 \\
\text { (reference) }\end{array}$ \\
\hline No & $\begin{array}{l}0.23(0.12 \\
0.42)\end{array}$ & $\begin{array}{l}0.15(0.05, \\
0.39)\end{array}$ & $\begin{array}{l}0.39(0.16 \\
0.91)\end{array}$ & $\begin{array}{l}0.68(0.29 \\
1.55) \#\end{array}$ \\
\hline
\end{tabular}

Multivariable logistic regression models to control for them using forward selection stepwise regression

\begin{tabular}{|c|c|c|}
\hline & \multicolumn{2}{|c|}{ Crude Estimates } \\
\hline Variables & $\begin{array}{l}\text { Crude Odd } \\
\text { Ratio (95\% } \\
\text { Cl) }\end{array}$ & P-value \\
\hline
\end{tabular}

Adjusted Estimates

Adj Odd
Ratio (95\%
Cl)

Immunization benefits: Association:

Immunisation benefit adjusted for Frequent provision of immunization at health facility on daily bases

3.96

$(1.35,11.53)$

0.012

$3.53(1.199$

0.022

Immunisation benefit adjusted for (Frequent provision of immunization at health facility on daily bases + Maternal Age (25-34 years) )

Immunisation benefit adjusted for (Frequent provision of immunization at health facility on daily bases + Maternal Age (25-34 years) + Health facility too far and no transportation to going for immunization)

vaccinator conduct outreach immunization

vaccinator conduct outreach immunization adjusted for immunisation benefit

vaccinator conduct outreach immunization adjusted for (immunisation benefit + Maternal age $(25-34$ years old $))$

vaccinator conduct outreach immunization adjusted for (immunisation benefit + Maternal age (25-34 years old) + Vaccinator visit during family livelihood business)

vaccinator conduct outreach immunization adjusted for (immunisation benefit + Maternal age (25-34 years old) + Vaccinator visit during family livelihood business + Not completed all the immunization for my child, not informed to come back)

vaccinator conduct outreach immunization adjusted for (immunisation benefit + Maternal age (25-34 years old) + Vaccinator visit during family livelihood business + Not completed all the immunization for my child, not informed to come back + Health facility too far and no

transportation to going for immunization)

\section{Vaccinator visit during family livelihood business :}

Vaccinator visit during family livelihood business adjusted for Availability of children immunization card

0.40

$(0.21,0.68)$

0.001

$0.35(0.19$

$0.64)$

2.05 3.39$)$

$2.18(1.25, \quad 0.005$

3.78)

$2.27(1.29, \quad 0.004$

3.96)

$2.26(1.29, \quad 0.004$

3.94)

$1.81(1.00$

3.25)

0.046

Vaccinator visit during family livelihood business adjusted for Availability of children immunization card + Functional facility type in the area)

Vaccinator visit during family livelihood business adjusted for Availability of children immunization card + Functional facility type in the area + Health facility conduct routine immunization outreach services

$\begin{array}{ll}0.32(0.17, & <0.001 \\ 0.59) & \\ 0.33(0.17, & 0.001 \\ 0.62) & \end{array}$

\# means it is not statistically significant ( $p$ value $>0.05$ )

Model 1: Association is adjusted for Maternal Age + parity + parent/guardian + child availability card

Model 2: Association is adjusted for immunisation benefit + community discussed + church discussed + Vaccinator visit during family livelihood business + BHWs + Health facility too far and no transportation to go for immunization.

Model 3: Association is adjusted for Functional facility type in the area + Health facility conduct routine immunization outreach services + vaccinator not happy + did not inform to come back + frequent provision of immunisation at the health facilities + inadequate notice + health facility conduct routine immunisation 
Multilevel multivariate logistics regression models to identify the predisposing factors that affected children between 0-23 months old living in South Sudan from being on track with their routine immunisation schedule.

\section{Health facility too far and no transportation to going for immunization :}

Health facility too far and no transportation to going for immunization adjusted for Functional facility type in the area

Health facility too far and no transportation to going for immunization adjusted for Functional facility type in the area + Inadequate notice about immunization outreach visit to community)

\section{Inadequate notice about immunization outreach visit to community}

Inadequate notice about immunization outreach visit to community adjusted for Maternal Age

Inadequate notice about immunization outreach visit to community adjusted for Maternal Age + vaccinator conduct outreach immunisation

Inadequate notice about immunization outreach visit to community adjusted for Maternal Age + vaccinator conduct outreach immunisation + Parity (above 6 children)

Inadequate notice about immunization outreach visit to community adjusted for Maternal Age + vaccinator conduct outreach immunisation + Parity (above 6 children) + Health facility too far and no transportation to going for immunization

Inadequate notice about immunization outreach visit to community adjusted for Maternal Age + vaccinator conduct outreach immunisation + Parity (above 6 children) + Health facility too far and no transportation to going for immunization + child card availability

Inadequate notice about immunization outreach visit to community adjusted for Materna Age + vaccinator conduct outreach immunisation + Parity (above 6 children) + Health facility too far and no transportation to going for immunization + child card availability + Vaccinator not happy for coming regularly to the community

\section{Churches discussed immunization importance}

Churches discussed immunization importance adjusted for county

Churches discussed immunization importance adjusted for county + Health facility too far and no transportation to go for immunisation

Churches discussed immunization importance adjusted for county + Health facility too far and no transportation to go for immunisation + Are you parent or guardian

Churches discussed immunization importance adjusted for county + Health facility too far and no transportation to go for immunisation + Are you parent or guardian + Vaccinator visit during family livelihood business

Churches discussed immunization importance adjusted for county + Health facility too far and no transportation to go for immunisation + Are you parent or guardian + Vaccinator visit during family livelihood business + Not completed all the immunization for my child, not informed to come back

Churches discussed immunization importance adjusted for county + Health facility too far and no transportation to go for immunisation + Are you parent or guardian + Vaccinator visit during family livelihood business + Not completed all the immunization for my child, not informed to come back + Functional facility type in the area

Churches discussed immunization importance adjusted for county + Health facility too far and no transportation to go for immunisation + Are you parent or guardian + Vaccinator visit during family livelihood business + Availability of children immunization card

Churches discussed immunization importance adjusted for county + Health facility too far and no transportation to go for immunisation + Are you parent or guardian + Vaccinator visit during family livelihood business + Availability of children immunization card + Frequent provision of immunisation at health facility

Churches discussed immunization importance adjusted for county + Health facility too far and no transportation to go for immunisation + Are you parent or guardian + Vaccinator visit during family livelihood business + Availability of children immunization card + Frequent provision of immunisation at health facility + Inadequate notice about immunization outreach visit to community
0.20

$(0.10,0.37)$

$<0.001$

0.14

$.26)$

$0.15(0.07,<0.001$

$0.28)$

\begin{tabular}{|c|c|c|c|}
\hline \multirow[t]{6}{*}{$\begin{array}{l}0.23(0.12 \\
0.42)\end{array}$} & \multirow[t]{6}{*}{$<0.001$} & $\begin{array}{l}0.11(0.04 \\
0.28)\end{array}$ & $<0.001$ \\
\hline & & $\begin{array}{l}0.10(0.03, \\
0.25)\end{array}$ & $<0.001$ \\
\hline & & $\begin{array}{l}0.10(0.03, \\
0.25)\end{array}$ & $<0.001$ \\
\hline & & $\begin{array}{l}0.11(0.04, \\
0.27)\end{array}$ & $<0.001$ \\
\hline & & $\begin{array}{l}0.12(0.04, \\
0.31)\end{array}$ & $<0.001$ \\
\hline & & $\begin{array}{l}0.14(0.05, \\
0.37)\end{array}$ & $<0.001$ \\
\hline
\end{tabular}

7.42

$(4.28,12.82)$

$<0.001$

5.01

$1.95(0.92$

4.13)

$2.02(0.87$

4.65)

$1.82(0.77$,

4.24)

$1.77(0.75$

4.18)

$1.93(0.80$

4.63)

$2.19(0.87$

5.47)

$2.26(0.89$

$5.72)$

$2.19(0.82$

5.82)
0.191

0.139

0.018

0.081

0.099

0.169

(1)

(1)

0.094 0.085

\# means it is not statistically significant ( $p$ value $>0.05$ )

Model 1: Association is adjusted for Maternal Age + parity + parent/guardian + child availability card

Model 2: Association is adjusted for immunisation benefit + community discussed + church discussed + Vaccinator visit during family livelihood business + BHWs + Health facility too far and no transportation to go for immunization.

Model 3: Association is adjusted for Functional facility type in the area + Health facility conduct routine immunization outreach services + vaccinator not happy + did not inform to come back + frequent provision of immunisation at the health facilities + inadequate notice + health facility conduct routine immunisation 
Multilevel multivariate logistics regression models to identify the predisposing factors that affected children between 0-23 months old living in South Sudan from being on track with their routine immunisation schedule.

Churches discussed immunization importance adjusted for county + Health facility too far and no transportation to go for immunisation + Are you parent or guardian + Vaccinator visit during family livelihood business + Availability of children immunization card + Frequent provision of immunisation at health facility + Inadequate notice about immunization outreach visit to community + Health Facility conduct routine immunisation outreach

\section{Community discussed immunization importance:}

Community discussed immunization importance: adjusted for Churches discussed immunization importance

Community discussed immunization importance: adjusted for Churches discussed immunization importance + Availability of children immunization card

Community discussed immunization importance: adjusted for Churches discussed immunization importance + Availability of children immunization card + Health facility too far and no transportation to going for immunization

Community discussed immunization importance: adjusted for Churches discussed immunization importance + Availability of children immunization card + Health facility too far and no transportation to going for immunization + Are you Parent/guardian of the child

Community discussed immunization importance: adjusted for Churches discussed immunization importance + Availability of children immunization card + Health facility too far and no transportation to going for immunization + Are you Parent/guardian of the child + Functional health facility types

Community discussed immunization importance: adjusted for Churches discussed immunization importance + Availability of children immunization card + Health facility too far and no transportation to going for immunization + Are you Parent/guardian of the child + Functional health facility types + Inadequate notice about immunization outreach visit to community

Community discussed immunization importance: adjusted for Churches discussed immunization importance + Availability of children immunization card + Health facility too far and no transportation to going for immunization + Are you Parent/guardian of the child + Functional health facility types + Inadequate notice about immunization outreach visit to community + Vaccinator visit during family livelihood business

Community discussed immunization importance: adjusted for Churches discussed immunization importance + Availability of children immunization card + Health facility too far and no transportation to going for immunization + Are you Parent/guardian of the child + Functional health facility types + Inadequate notice about immunization outreach visit to community + Vaccinator visit during family livelihood business + Not completed all the immunization for my child, not informed to come back

Community discussed immunization importance: adjusted for Churches discussed immunization importance + Availability of children immunization card + Health facility too far and no transportation to going for immunization + Are you Parent/guardian of the child + Functional health facility types + Inadequate notice about immunization outreach visit to community + Vaccinator visit during family livelihood business + Not completed all the immunization for my child, not informed to come back + Parity (above 6 children)

Community discussed immunization importance: adjusted for Churches discussed immunization importance + Availability of children immunization card + Health facility too far and no transportation to going for immunization + Are you Parent/guardian of the child + Functional health facility types + Inadequate notice about immunization outreach visit to community + Vaccinator visit during family livelihood business + Not completed all the immunization for my child, not informed to come back + Parity (above 6 children) + Frequent provision of immunisation at health facility

Community discussed immunization importance: adjusted for Churches discussed immunization importance + Availability of children immunization card + Health facility too far and no transportation to going for immunization + Are you Parent/guardian of the child + Functional health facility types + Inadequate notice about immunization outreach visit to community + Vaccinator visit during family livelihood business + Not completed all the immunization for my child, not informed to come back + Parity (above 6 children) + Frequent provision of immunisation at health facility + Health facility conduct routine immunisation outreaches
$2.09(0.78$

0.141

\begin{tabular}{|c|c|c|c|}
\hline \multirow[t]{5}{*}{$\begin{array}{l}7.76 \\
(4.50,13.36)\end{array}$} & \multirow[t]{5}{*}{$<0.001$} & $\begin{array}{l}3.62(1.42, \\
9.18)\end{array}$ & 0.007 \\
\hline & & $\begin{array}{l}2.22(0.85 \\
5.80)\end{array}$ & 0.103 \\
\hline & & $\begin{array}{l}2.22(0.85, \\
5.74)\end{array}$ & 0.099 \\
\hline & & $\begin{array}{l}1.94(0.74, \\
5.07)\end{array}$ & 0.178 \\
\hline & & $\begin{array}{l}1.38(0.47, \\
3.97)\end{array}$ & 0.551 \\
\hline
\end{tabular}

$1.13(0.36$,

3.43)

0.836

$1.13(0.37$

0.829

3.364)

$1.23(0.40$

3.71)

0.711

$1.18(0.38$

0.777

3.59)

$1.24(0.39$,

0.713

3.84)

$1.29(0.40$

4.05)

0.665

\# means it is not statistically significant ( $p$ value $>0.05$ )

Model 1: Association is adjusted for Maternal Age + parity + parent/guardian + child availability card

Model 2: Association is adjusted for immunisation benefit + community discussed + church discussed + Vaccinator visit during family livelihood business + BHWs + Health facility too far and no transportation to go for immunization.

Model 3: Association is adjusted for Functional facility type in the area + Health facility conduct routine immunization outreach services + vaccinator not happy + did not inform to come back + frequent provision of immunisation at the health facilities + inadequate notice + health facility conduct routine immunisation

The findings were further supported by the results in the multilevel multivariable logistic regression models that adjusted for potential confounders in a 3multilevel model - maternal and child (model 1a), community (model 2b) and state health systems (model 3c), see Table 3 . The study found that children 
cared by mothers or guardians with 6 and more children were $60 \%$ less likely to be off track with immunization than those with 1 child. The odds of children being off track with immunization increased for children whose mothers reported that immunization was essential for child growth compared to protection against diseases (AoR 7.45,95\% Cl 2.06-26.87). Children whose mothers reported that vaccinators did not visit during family business and livelihoods and had no means of getting to the health facility were $57 \%$ and $83 \%$ less likely to be off track within immunization. The chances of being off track with immunization increased among children whose mother reported that vaccinators did not conduct outreach services (AoR 7.21, 95\% $\mathrm{Cl} 3.82,13.5)$, and lack of discussion by the community ( $\mathrm{AoR} 8.01,95 \% \mathrm{Cl} 4.02,15.92)$ and churches (AoR 7.62, 95\% $\mathrm{Cl} 3.90,14.87$ ) on the importance of immunization.

\section{Discussion}

This study analysed the factors that influence children aged 0-23 living in South Sudan to be off track with their routine immunization schedule. We found that $75.5 \%$ of the participants were off track and that the percentage of off track status increased in subsequent vaccine doses. These similar findings have also been reported in a study in Ethiopia that showed decreasing immunization coverage in subsequent vaccine doses (25). The high prevalence of off track children was found to be driven mainly by community and state-level variables. A child who did not attend a church that discussed immunization importance was more than 2 times more likely to be off track with immunisation than children who went to a church that discussed immunization importance. A child whose community leaders did not discuss immunization importance was more than 3 times more likely to be off track than a child whose community leader did. Additionally, the probability of a child being off track was reduced by $85 \%$ when mothers and caregivers were given adequate notice about immunization outreach. In relation to this, vaccinators conducting outreach immunization were shown to be influential in that children without this service were 2 times more likely to be off track than children with access to outreach immunization. Furthermore, children who did not have vaccinators during family livelihood business were about $70 \%$ less likely to be off track. When it came to mothers and caregivers and their thoughts towards immunization, children were more than 4 times more likely to be off track if they had mothers who believed the benefits of immunization is for child growth compared to protection against diseases. Additionally, children who had 6 siblings or more were up to $60 \%$ less likely to be off track compared to being an only child. Not only was the outcome dependent on community factors, but also geographical factors in that living close to health facilities and having transportation reduced a child's chances of being off track by $85 \%$.

Churches that did not discuss immunization importance were found to be a strong predictor of being off track with immunization. This finding is supportive of the role religious platforms play as influential sources for educating and communicating the essence of immunization to their worshippers. However, a study in Nigeria reported that religious leaders have proved reluctant to recommend vaccination to their followers on behalf of health authorities (26), this could be as a result of their belief that vaccination is against the will of God as seen in the case of Benin (27). It is to be noted that our study did not investigate whether and to what extent churches and worship centres are involved in immunization activities, there is the need to review the policy guiding the roles and involvement of churches, and other religious centers in planning and implementing immunization programmes at the community level, as well as monitoring vaccine utilization. Similarly, a child whose community leader did not discuss immunization importance was more than 3 times more likely to be off track than a child whose community leader did. This finding justifies the need for the active involvement of community leaders in driving immunisation programme success. The finding corroborated a study in Nigeria (28) which reported that efforts of community leaders to create immunization awareness influenced the knowledge of mothers on immunization benefits. This finding also corroborated a study which focused on community engagement, routine immunization, and polio legacy in Northern Nigeria, a similar conflict context area with a long history of poor immunization and health performance (29). Another study showed that the quality and volume of immunization and health information available in mothers' social environment influenced the uptake of immunization services (30). In the case of this study, the quality and volume of immunization information would be promoted by means of community leaders. There is a need to review the role of community leadership in promoting immunization education taking into account the limited higher learning health institutions and resources, especially for girls and women, to strengthen community health education flow. We observed that the probability of a child being off track was reduced by $85 \%$ when mothers and caregivers were given adequate notice prior to immunization outreach. This finding is a reflection of the benefit around optimization of immunization outreaches conducted with adequate notice to mothers and caregivers, and encourages the enhanced application of it to our study population. The finding was supported by WHO's Immunization in practice: a practical guide for health staff that identified inadequate prior notice to immunisation as one of the barriers to vaccine utilisation (31). In order to achieve an effective immunization outreach program, a micro-plan that involves rigorous communications with community stakeholders during the pre- or post-planning process should be implemented. Existing EPI micro-plans should be reviewed for areas where services are not optimized to reflect what works best, commonly, for all stakeholders. The micro-plan developed in consultation with the benefiting communities, should have social mobilization well integrated in it as outreach activity is partially determined by the robustness of social mobilizers' commitment (see Fig. 1). Furthermore, the commitment and quality of social mobilizers should be reestablished to ensure communities, government and the donors are not being short-changed with inadequacy or non provision of services. Since social mobilizers are engaged as a matter of policy in implementing immunization outreaches, immunization programme managers should ensure that mobilizers have good knowledge of the area they are to cover, comfortable to work in these insecure areas and are accepted by their assigned community. Otherwise, the use of multiple mobilizers may be adopted by communities with wide land mass or with security challenges. Social mobilizers and EPI Vaccinators providing outreach services should be regularly supported, mentored and monitored (SMM) to improve integration and deliver quality immunization services. In this regard, we recommend not more than two to three immunisation sessions per week with more days available for adequate social mobilisation. Furthermore, as seen in the study's results, children who did not have vaccinators during family livelihood business were about $70 \%$ less likely to be off track. In a study conducted in Burkina Faso, mothers who gave more concern to their business were found not to have their children with full vaccination (32). The finding gave a pointer to the existence of children with incomplete vaccination, perhaps as a mark of clash of interest between mothers/caregivers' livelihood business and timing for immunization. This reiterates the usefulness of a well planned and coordinated vaccination plan with input from various interests including the working mother population.

This study observed that health facilities frequently conducting routine (static) immunization services on a daily basis were influential in reducing the amount of children off track with immunization. Policy on immunization in South Sudan advises the implementation of routine immunization outreach across communities outside the $5 \mathrm{~km}$ radius of a health facility $(1,33,34)$. Considering the need for improvement of immunization success in countries like South 
Sudan, continuous vaccine availability and punctuality of EPI vaccinators at health facilities, creation and sustainability of more outreach posts with regular supplementary immunisation activities in hard-to-reach areas could translate into higher vaccine uptake. The above mixed intervention should be evaluated regularly to ensure communities, government and the donors get appropriate service and value for immunisation programmes. While promoting staff retention is important to achieving sustained progress, vaccinators who are found deficient with low-commitment should be given refreshers' training while those with repeated underperformance should be let go in order to engage committed ones. We also recommend the continual usage of performance incentives to pay vaccinators for services rendered; and for every falsehood identified in the immunization accountability conducts and reports, sanctions should be designed. To promote the effectiveness of performance based incentives, an improved system of accountability has to be put in place. There is an urgent need for South Sudan to put forward a clear policy and implementable strategies on training of vaccinators, and/or who should be responsible for vaccination delivery at health facilities and within communities. State immunization performance monitoring and evaluation strategy must be reviewed at least twice in a year, and interventions should be fashioned to model collaborative, iterative and inclusive and targeted problem solving approaches. According to a unicef report, a 'onesize-fits-all' approach in this changing world is no longer appropriate (35). Nevertheless, analysis of data available from DHIS2 have shown more vaccination still takes place during outreaches activities for most counties in south Sudan $(1,36)$.

When it came to mothers/ caregivers and their thoughts towards immunization, children had a higher odds of being off track if they had mothers who believed the benefits of immunization is for child growth compared to protection against diseases. Extensive evidence has also consistently listed child protection from diseases as a primary benefit from complete vaccination of children $(37,38)$. Interestingly, our sampled mothers place higher value on good child growth as the benefit of immunisation rather than protection against diseases to their children. In this regard, we recommend educating caregivers on the benefits of immunization as it has a great influence on immunization uptake (see Fig. 1).

In this study, it was noted that mothers who had 6 or more children had a lower odds of being off track compared to those whose mothers had one child. Studies conducted in Liberia and another in Kenya showed a reduced chance of completion of vaccination for children with 2-3 siblings but the chance of completion increased for children with 4 siblings and above, when compared to one child only (39). Studies conducted in Liberia and another in Kenya showed a reduced chance of completion of vaccination for children with 2-3 siblings but the chance of completion increased for children with 4 siblings and above, when compared to one child only. This finding is contrary to the reports from Eastern Ethiopia (OR 3.55, Cl: 1.32-9.58) (40) and West Africa that showed higher odds of defaulting from immunization with mothers of higher parity (41).

Not only was the outcome dependent on community factors, but also geographical factors in that living close to health facilities and having transportation reduced a child's chances of being off track by $85 \%$. This finding demonstrates the importance of health equity and increasing immunization access to hardto-reach and far communities. This study finding is in line with a study conducted in Kenya that showed mothers residing about $>5 \mathrm{~km}$ from a health facility (OR 1.6, Cl1.1-3.1) were more likely to default from completing vaccination (39). Contrarily, studies conducted in Mali (OR:0.6, Cl: 0.4-0.8) and Niger (OR :0.8, $0.6-1.0)$, showed that living closer to health facilities was not associated with complete vaccination of children (41). Activities that positively influence health seeking behaviour and immunization information sharing should be promoted to optimise immunization service utilization. While it may be a good recommendation based on the study finding for government and partners to establish more health facilities considering its potential benefits to immunization and population health generally, location and localization of health facilities are governed by other factors including population and resources which may not immediately support that. Hence, a proper assessment of the health (facility) needs is highly recommended. Political influence in the positioning of health facilities should be minimized if it cannot be completely stopped. Robust implementation and coordination between the health facility, outreach and mobile immunisation services should be urgently considered as they could be ideal in reducing the amount the caregivers use in transportation costs.

In all, this study has revealed that improving immunization coverage requires strengthening community health systems, and this should remain a key priority for government and major health partners.

\section{Study Limitation}

This cross-sectional study is reported in accordance with the 22- item checklist that are considered highly essential by the STROBE- strengthening the Reporting of Observational Studies in Epidemiology statement; however, this study would have had more improved quality if a well-structured survey with a variety of variables. In addition, we acknowledge bias in the study questionnaire like social desirability bias as a result of mothers who may have given inaccurate answers in an effort to be viewed more favorably as well as interviewers' bias or influence would have occurred from the integrated community case management $\{(I C C M)$ or Boma health\} workers with the tendency of the interviewer to obtain answers that support preconceived notions, while writing on behalf of mothers who were unable to read and write. Infact, bias as a result of a non- standardized measurement of conflict or risk intensity among these counties which could have had an association with the immunisation uptake coverage in these respective counties at the time of the study. This study could not assess the timeliness of vaccine uptake by children, and also recommend further studies with a larger sample size with more equal sampling across the counties for more comparable conclusions. We also admit differential misclassification of caregivers or mothers may have occurred with adopted children in the class of mothers with a higher parity; in addition to that, excluding children of mothers who reported the child is being immunised but with untraceable immunisation data records from the study could also have resulted in selection bias and non-differential misclassification and could have underestimated the proportion of the groups of children being on and off track with their immunisation schedule. Lastly, we also acknowledge that residual confounding may have occurred in the grouping of mother and child's ages, parity, distance to health facility.

\section{Conclusion}

This study showed that there is a high prevalence of children being off track with their immunisation schedule that is mainly driven by community- and statelevel immunisation service delivery mechanism factors. Most suitable interventions to improve child immunisation uptake was also recommended. This study 
is advisable not to be generalized into a non-conflict context, nevertheless, we strongly recommend regular evaluation of the performance of the health system in the delivery of vaccines to the community.

\section{Declarations}

\section{Ethics approval and consent to participate}

The study protocol and conduct adhered to the principles laid down in the Declaration of Helsinki. Ethics approval for this study was granted by the Health Research Ethics Committee of the State Ministry of Health (SMoH) of Lakes State (formerly Western Lakes State), South Sudan. The immunisation uptake data used in this study is based on mothers of children eligible for all the vaccine doses in the South Sudan' immunisation schedule. Children and parents/adult carers were not involved in setting the research question or the outcome measures; however, the study results were solely based on their response to the survey questions.

\section{Consent for publication}

Signed informed consent for publication was obtained from all study participants before data collection.

\section{Availability of data and material}

The datasets used and/or analysed during the current study are available from the corresponding author on reasonable request.

\section{Competing interests}

The authors declare no conflict of interest that might have influenced the work in this paper.

\section{Funding}

This study was conducted with no fund support from an organization.

\section{Authors' contributions:}

IOI conceptualized this study, organised data collection and management, planned the methodology, analyzed the data, wrote the first draft and participated in the final draft writing. JT planned the methodology, participated in data management, analyzed the data, participated in the first draft and the final draft writing. GK participated in data analysis and final draft writing. GOA was involved in study conceptualization, participated in data collection, and final draft writing. FIA participated in writing the final draft. JGO was involved in the study conceptualization, supervised data collection and reviewed the final manuscript draft. All authors reviewed the final manuscript draft, and approved the submitted manuscript.

\section{Acknowledgement}

The authors would like to thank the boma health workers who supported the data collection; participants who participated in this study; and in particular the South Sudan Ministry of health represented by the state surveillance officer - Gordon Mayen.

\section{References}

1. IdrisIO,LamidiSA,OchaguVA,TapkigenJ,ObwoyaJG,AbbasK.Impactevaluationofimmunisationserviceintegrationtonutritionprogrammesandpediatricoutpatie

2. WHO.South Sudan: WHO and UNICEF estimates of immunization coverage: 2019 revision.WHO and UNICEF;2020.

3. South Sudan (SSD)-Demographics,Health\&InfantMortality-UNICEFDATA[Internet].[cited2021Apr18].Availablefrom:https://data.unicef.org/country/ssd/

4. WHO AFRO.Integrated Disease Surveillance and Response (IDSR).WHO AFRO;2020Mar.

5. South Sudan vaccinates over 690000 childrenagainstmeaslesin25counties|WHO|RegionalOfficeforAfrica[Internet]. [cited2021Jun27].Availablefrom:https://www.afro.who.int/news/south-sudan-vaccinates-over-690-000-children-against-measles-25-counties

6. AmidChallenges,SouthSudanVaccinationDriveTacklesMeasles|VoiceofAmerica-English[Internet]. Voanews.

[cited2021Jun24].Availablefrom:https://www.voanews.com/africa/amid-challenges-south-sudan-vaccination-drive-tackles-measles

7. WHO

Afro.SouthSudanstrategizestowardsstrengtheningthehealthsystemstoimprovethequalityandcoverageofimmunizationservices|RegionalOfficeforAfrica[InteI 
8. RaslanR,EISayeghS,ChamsS,ChamsN,LeoneA,Hajj Husseinl.Re-Emerging Vaccine-Preventable Diseases in War-Affected Peoples of the Eastern Mediterranean Region-An Update.Front Public Health. 2017 Oct25;5:283.

9. SmithPJ,ChuSY,BarkerLE.Children who have received no vaccines: who are they and where do they live? Pediatrics.2004Jul;114(1):187-95.

10. PeckM,Gacic-DoboM,DialloMS,NedelecY,SodhaSV,WallaceAS.Global routine vaccination coverage, 2018.MMWR Morb Mortal Wkly Rep. 2019 Oct25;68(42):937-42.

11. Ministry of Health, Republic of South Sudan.RepublicofSouthSudanMultiyearPlanforlmmunization,2012-2016.RepublicoofSouthSudan;2012Jan.

12. Clayton Hazvinei Vhumbunu.TheFormationoftheRevitalizedTransitionalGovernmentofNationalUnityinSouthSudan-ACCORD[Internet].Accord. [cited2021Jun24].Availablefrom:https://www.accord.org.za/conflict-trends/the-formation-of-the-revitalized-transitional-government-of-national-unity-insouth-sudan/

13. UN Peacekeeping.WomeninLakescallonpartiestoquicklyimplementrevitalizedpeaceagreement|UnitedNationsPeacekeeping[Internet]. [cited2021Jun24].Availablefrom:https://peacekeeping.un.org/en/women-lakes-call-parties-to-quickly-implement-revitalized-peace-agreement

14. South Sudan:AdministrativeDivision(StatesandCounties)-PopulationStatistics,ChartsandMap[Internet]. [cited2021Jun24].Availablefrom:https://www.citypopulation.de/en/southsudan/admin/

15. UNDP,Bureau for Community Security and Small Arms Control,South Sudan Peace and Reconciliation Commission. Community Consultation Report Lakes state South Sudan.Juba, South Sudan:UNDP;2012May.

16. Médecins Sans Frontières/Doctors Without Borders (MSF).SouthSudan:HeavyfloodsthreatensthelivesofthousandsofpeopleinGreaterPiborAdministrativeAreaSouthSudan|ReliefWeb[Internet].Reliefweb.2020[cited2021Jun24].Availablefrom:https://reliefweb.int/report/south-sudan/south-sudan-heavy-floodsthreatens-lives-thousands-people-greater-pibor

17. ChoudharyTS,ReddyNS,ApteA,SinhaB,RoyS,NairNP,etal.Delayed vaccination and its predictors among children under 2 years in India: Insights from the national family health survey-4.Vaccine. 2019 Apr17;37(17):2331-9.

18. IdrisIO,OguntadeAS,MensahEA,KitamuraN.Prevalence of non-communicable diseases and its risk factors among ljegun-Isheri Osun residents in Lagos State, Nigeria: a community based cross-sectional study.BMC Public Health.2020Aug18;20(1):1258.

19. LachenbruchPA,LwangaSK,LemeshowS.Sample size determination in health studies: A practical manual.J Am Stat Assoc.1991Dec;86(416):1149.

20. MalualAC,JowiY,IrimuG,AdmaniB.MissedopportunitiesforimmunizationamongchildrenattendingaPaediatricOutpatientClinicatJubaTeachingHospital.South 2018/missed-opportunities-for-immunization-among-children-attending-a-paediatric-outpatient-clinic-at-juba-teaching-hospital.html

21. EtanaB,DeressaW.Factors associated with complete immunization coverage in children aged 12-23 months in Ambo Woreda, Central Ethiopia.BMC Public Health.2012Jul28;12:566.

22. OrganizationWH.Methodology for the assessment of missed opportunities for vaccination. World Health Organization;2017.

23. Pan American Health Organization.Methodology for the evaluation of missed opportunities for vaccination.PAHO;2013.

24. ManziA,MunyanezaF,MujawaseF,BanamwanaL,SayinzogaF,ThomsonDR,etal.Assessing predictors of delayed antenatal care visits in Rwanda: a secondary analysis of Rwanda demographic and health survey 2010.BMC Pregnancy Childbirth.2014Aug28;14(1):290.

25. GirmayA,DadiAF.Full Immunization Coverage and Associated Factors among Children Aged 12-23 Months in Hard-to-Reach Areas of Ethiopia.Int $J$ Pediatr.2019May27;2019:1924941

26. RuijsWLM,HautvastJLA,KerrarS,van derVeldenK,HulscherMEJL. The role of religious leaders in promoting acceptance of vaccination within a minority group: a qualitative study.BMC Public Health.2013May28;13:511.

27. FournL,HaddadS,FournierP,GanseyR.Determinantsofparents'reticencetowardvaccinationinurbanareasinBenin(WestAfrica).BMCIntHealthHumRights.20090

28. OlaniyanA,IsiguzoC,HawkM. The Socioecological Model as a framework for exploring factors influencing childhood immunization uptake in Lagos state, Nigeria.BMC Public Health.2021May5;21(1):867.

29. McArthur-LloydA,McKenzieA,FindleySE,GreenC,AdamuF.Community engagement, routine immunization, and the polio legacy in northern nigeria.Global Health Communication.2016Jan;2(1):1-10.

30. HarmsenIA,RuiterRAC,PaulussenTGW,MollemaL,KokG,deMelkerHE.Factors that influence vaccination decision-making by parents who visit an anthroposophical child welfare center: a focus group study.Adv Prev Med.2012Nov20;2012:175694.

31. World Health Organisation.Immunization in Practice: A practical guide for health staff.World Health Organisation,editor.2015.

32. KagonéM,YéM,NébiéE,SiéA,MüllerO,BeiersmannC.Community perception regarding childhood vaccinations and its implications for effectiveness: a qualitative study in rural Burkina Faso.BMC Public Health.2018Mar6;18(1):324.

33. UNICEF.National Immunization Coverage Survey Final Report.UNICEF;2017.

34. South SudanMofH.MinistryofHealth,GovernmentofSouthernSudan.BasicPackageofHealthandNutritionServicesForSouthernSudanPDFFreeDownload[Internet].MinistryofHealth,SouthSudan;2009Jan[cited2021Apr18].Availablefrom:https://docplayer.net/9884924-Ministry-of-healthgovernment-of-southern-sudan-basic-package-of-health-and-nutrition-services-for-southern-sudan.html

35. United Nations Children's Fund (UNICEF).ImmunizationRoadmap2018-2030.2018Sep;

36. South SudanHMIS[Internet].[cited2021Apr18].Availablefrom:https://www.southsudanhis.org/dhis-web-commons/security/login.action

37. European Vaccination Information Portal.Benefitsofvaccinationforthecommunity[Internet].[cited2021Jun27].Availablefrom:https://vaccinationinfo.eu/en/vaccination/benefits-vaccination-community

38. CDC.WhylsVaccinationImportantandWhatAretheBenefits?|[Internet].[cited2021Jun27].Availablefrom:https://www.cdc.gov/vaccines/growing/ 
39. HajiA,LowtherS,Ngan'gaZ,GuraZ,TabuC,SandhuH,etal.Reducing routine vaccination dropout rates: evaluating two interventions in three Kenyan districts, 2014.BMC Public Health. 2016 Feb16;16(1):152.

40. YenitMK,GelawYA,ShiferawAM.Mothers' health service utilization and attitude were the main predictors of incomplete childhood vaccination in eastcentral Ethiopia: a case-control study.Arch Public Health.2018Dec;76(1):14.

41. KazunguJS,AdetifalMO.Crude childhood vaccination coverage in West Africa: Trends and predictors of completeness. [version 1; peer review: 1 approved, 3 approved with reservations].Wellcome Open Res. 2017 Feb15;2:12.

\section{Figures}

\section{Figure 1. A Framework to Tackle the Predisposing Factors That Affects Children Living in South Sudan from Being on Track with Their Routine Immunisation Schedule.}

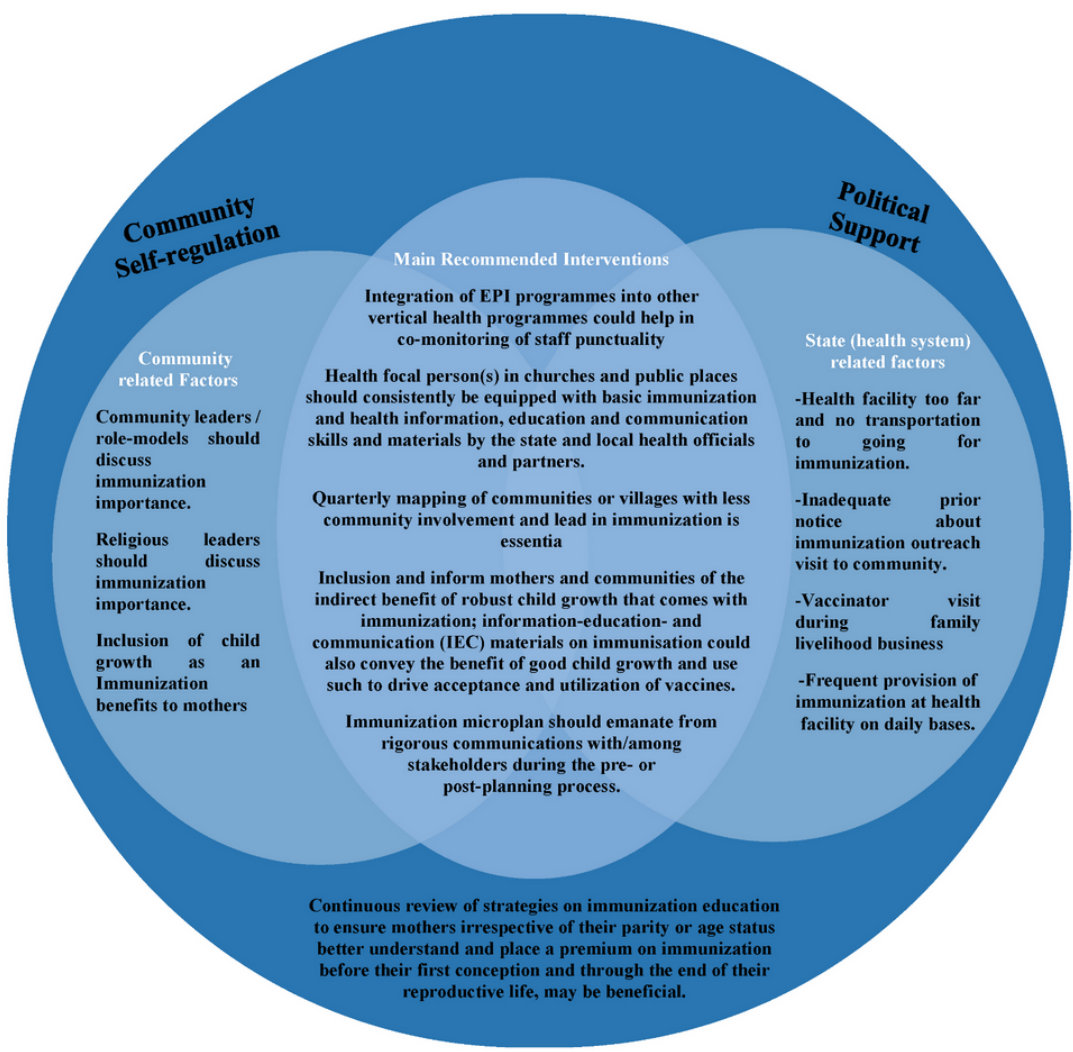

Key Points to Tackle the Predisposing Factors of Children Being Off-Track with Their Immunisation Schedule in South Sudan

\section{Figure 1}

A Framework To Tackle The Predisposing Factors That Affects Children Living in South Sudan From Being on Track With Their Routine Immunisation Schedule. 


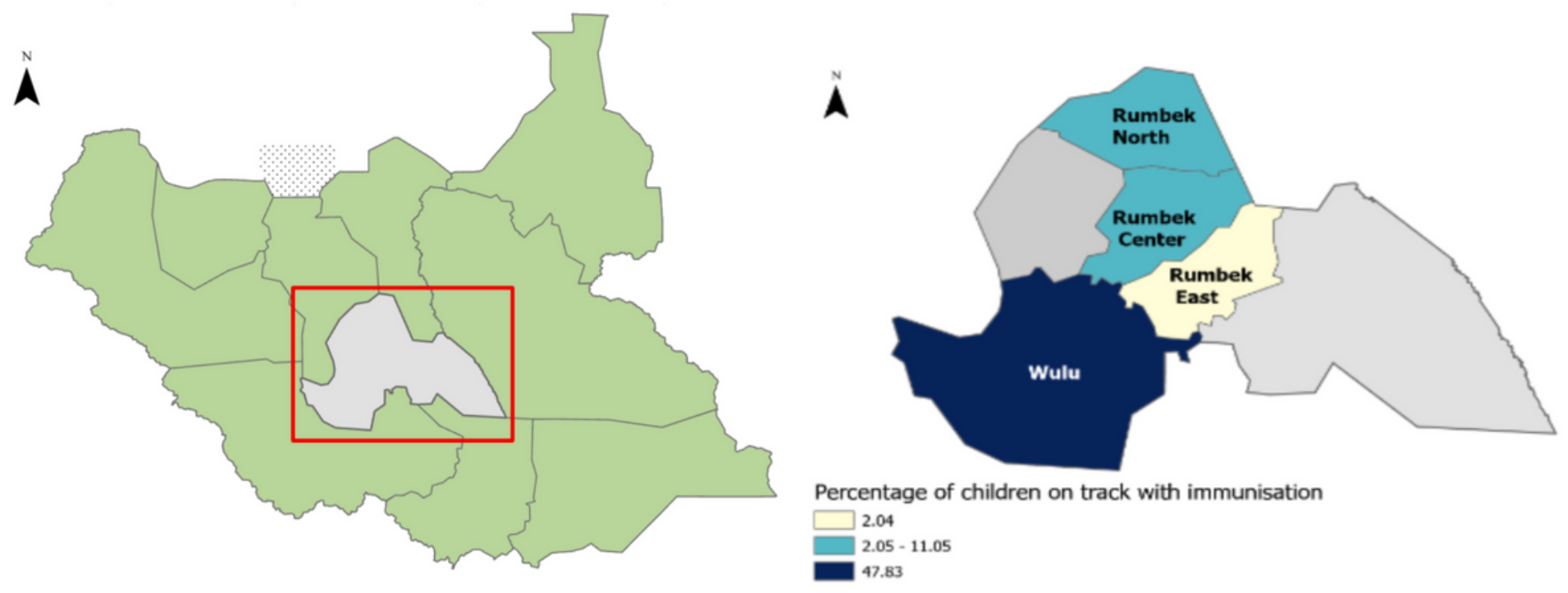

\section{Figure 2}

This figure contains 2 maps of the former Western Lakes state. The left map shows the geography location of the former Western Lakes in South Sudan and its four counties - Rumbek Centre, Rumbek North, Rumbek East, and Wulu. The Western Lakes State is known to be an area of protracted conflict, affecting health related outcomes including immunisation timeliness. The second map shows the percentage of the sampled children aged 0-23 months living in the 4 counties in the Western Lakes State of South Sudan who were on track with their routine immunisation schedule during the survey.

A

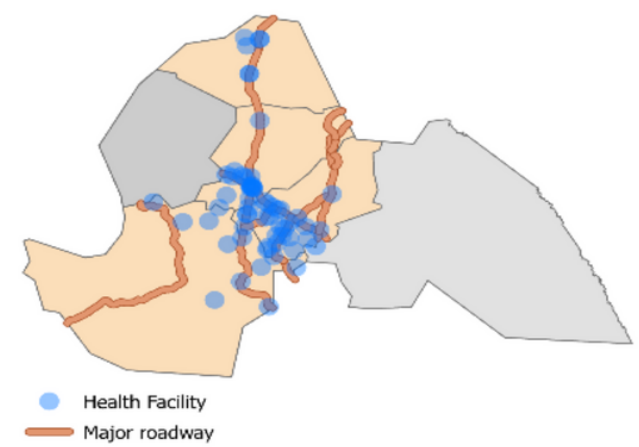

A

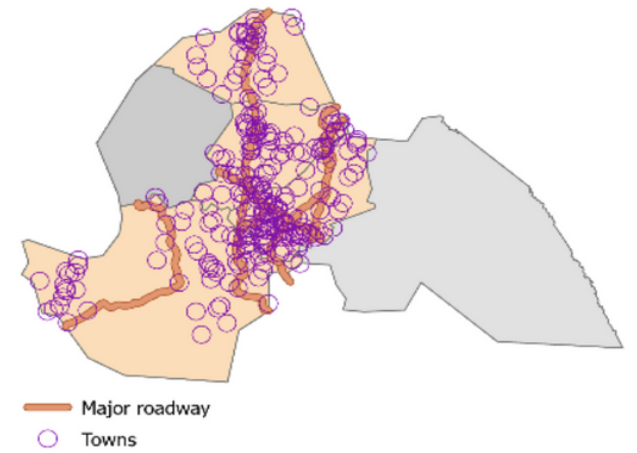

A

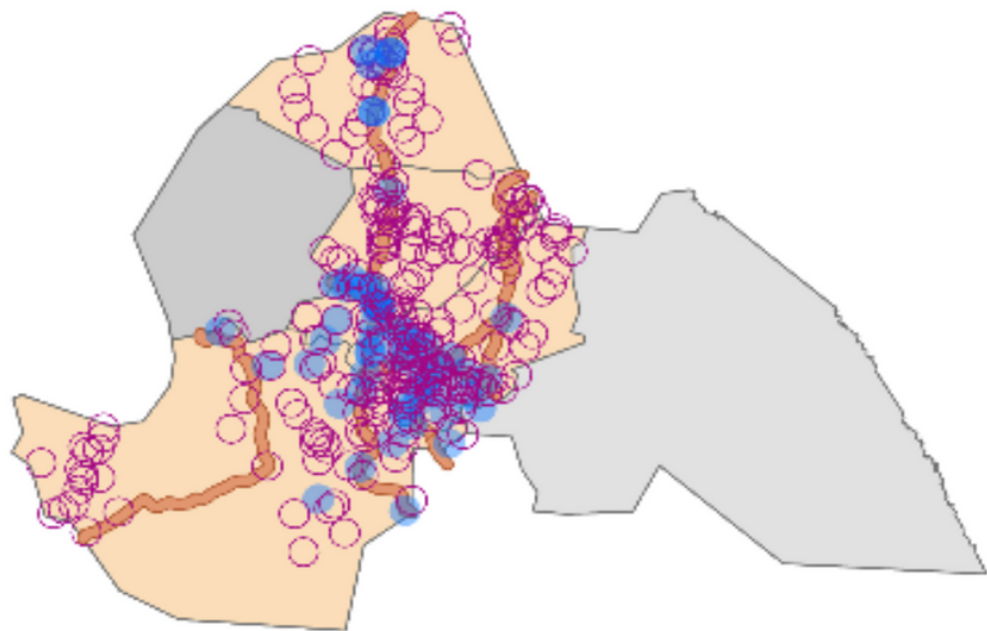

Health Facility

Major roadway

(C) Towns

Figure 3 
The figure has three maps showing the major towns, road and health facilities in the four counties (Rumbek North, Rumbek Centre, Rumbek East and Wulu) of the Western Lakes state.

\section{Supplementary Files}

This is a list of supplementary files associated with this preprint. Click to download.

- QuestionnairePREDISPOSINGFACTORSFORIMMUNIZATIONDEFAULTINGAMONGUNDERONEOFHTRCOMM1.docx 